\title{
Olfactory dysfunction revisited: a reappraisal of work-related olfactory dysfunction caused by chemicals
}

\author{
Sabine Werner ${ }^{*}$ (D) and Eberhard Nies
}

\begin{abstract}
Occupational exposure to numerous individual chemicals has been associated with olfactory dysfunction, mainly in individual case descriptions. Comprehensive epidemiological investigations into the olfactotoxic effect of working substances show that the human sense of smell may be impaired by exposure to metal compounds involving cadmium, chromium and nickel, and to formaldehyde. This conclusion is supported by the results of animal experiments. The level of evidence for a relationship between olfactory dysfunction and workplace exposure to other substances is relatively weak.
\end{abstract}

Keywords: Chemically induced anosmia, Formaldehyde, Metals, Occupational exposure, Olfaction disorders

\section{Background}

Many occupational groups are reliant upon intact olfactory function in order to perform their work and for their safety. Examples are chefs, gas fitters, firefighters, perfumers, sommeliers, coffee and tea tasters, grocers, workers in the chemical industry, and domestic helpers. The importance of the olfactory function for early detection of hazardous substances with an odour is illustrated by the specific case of an anosmic who lit a cigarette whilst in close proximity to a leaking petrol pipe, thereby causing an explosion [1]. Muttray et al. [2] report the case of a patient who did not become aware of his olfactory dysfunction until his colleagues fled their workplace, to him for no apparent reason, owing to an intense solvent smell. In Germany, an assessment of olfactory function is a requirement for persons applying for certification of their fitness to perform fumigation [3], and loss of olfactory function constitutes grounds for example for the discharge of members of the US military, including reservists, and of coastguard employees [4].

\footnotetext{
* Correspondence: Sabine.Werner@dguv.de

Institute for Occupational Safety and Health of the German Social Accident Insurance, Unit Toxicology of Industrial Chemicals, Alte Heerstrasse 111,

53757 Sankt Augustin, Germany
}

(c) The Author(s). 2018 Open Access This article is distributed under the terms of the Creative Commons Attribution 4.0 International License (http://creativecommons.org/licenses/by/4.0/), which permits unrestricted use, distribution, and reproduction in any medium, provided you give appropriate credit to the original author(s) and the source, provide a link to the Creative Commons license, and indicate if changes were made. The Creative Commons Public Domain Dedication waiver (http://creativecommons.org/publicdomain/zero/1.0/) applies to the data made available in this article, unless otherwise stated.

\section{Diagnosis and assessment of olfactory dysfunction}

Assessment of olfactory function and diagnosis of olfactory dysfunction requires, firstly, a detailed medical history and examination by an otolaryngologist $[5,6]$. The medical history should include information on the triggering events, development, complementary symptoms, surgical operations, medication and toxicants. The ENT diagnosis comprises medical status, endoscopy of nose and nasopharyngeal space and evaluation of the olfactory cleft. If a neurological disorder is suspected, an examination by a neurologist including tests of cognition and memory could be necessary. Secondly, a validated test method is needed that enables subjective sensory perceptions to be quantified objectively. This is essential for a standardised distinction between normosmia (normal olfactory function), hyposmia and anosmia (impaired olfactory function and its complete loss, respectively), and hyperosmia (olfactory oversensitivity). A screening of global taste function (retronasal smelling) is also advantageous owing to the close connection between smell and taste (patients complaining of a dysfunctional sense of taste are in fact often suffering from olfactory impairment).

Only in the last three decades have standardised and practicable psychophysical tests for humans been developed. Of these, UPSIT (University of Pennsylvania Smell 
Identification Test [7]) and the "Sniffin' Sticks" test widely used in Europe [8, 9], are important examples.

"Sniffin' Sticks" are felt sticks that release aromatic substances when the cap of the stick is removed. In conventional form, they permit threshold, discrimination and identification tests; the last two of these are above-threshold tests. The threshold test indicates the concentration above which an odour is sensed (the sensory threshold). As standard, n-butanol or phenyl ethyl alcohol (rose scent) are used for testing. The non-verbal discrimination test examines the ability to distinguish between odours. In the identification test, 16 odours are tested for recognition [10]. This is a structured, reliable and validated test system that is widely used in Europe and is readily available. Extensive validation studies and defined standard values exist for this test [11, 12]. Regularly updated standardised values are published for example on the website of the Interdisciplinary Center Smell \& Taste (University Clinic Dresden) [13].

A similar identification test used in America is the UPSIT method, in which up to 40 odorants, microencapsulated on a sheet of paper, are released by scratching with the point of a pencil. In this test, the various odorants must be identified with reference to a list of four terms per substance. The test kit has a long shelf life, is very well validated and is widely used. The UPSIT test does not require clinician supervision and is therefore very convenient. International versions are also available; they have however rarely been validated specifically for individual countries. A drawback of the test is that it studies only the identification of odours.

Where patients might not be able to comply with psychophysical testing, or in medico-legal assessments, the olfactory dysfunction can be assessed objectively by recording electrical activity of the brain (olfactory event-related potentials, OERPs) following presentation of odours. This method requires virtually no active participation on the part of the test subject, and has been used since the 1970s. It involves the application of olfactory stimuli to the nose of the test subject with the aid of an olfactometer. The stimuli trigger corresponding OERPs, which can then be registered on electrodes applied to the test subject's head. The use of an electro-olfactograph (the recording of generator potential via an electrode in contact with the olfactory epithelium) is limited to research. Olfactory functional imaging methods such as PET (positron emission tomography) and fMRI (functional magnetic resonance imaging) are also largely limited to research applications $[5,6]$.

Important information on the toxic properties of inhaled substances that may affect olfaction has been obtained from experiments on animals. Besides histological analyses of the olfactory epithelium, the results of behavioural tests are also relevant. Since the laboratory animal is not able to communicate actively to the researcher whether or not it senses an odour, an operant conditioning test is usually performed. In such a test, mice for example are first taught to expect a reward (such as water following restricted access to water) after sensing a certain olfactory stimulus. The animals are then presented with other odours that are not followed by a reward, in addition to the odour that they have learnt to associate with the reward. Where the animal has recognised the correct odour and looks for its reward, this can be registered, for example by means of a light barrier (for a detailed description, see Kuner and Schaefer 2011 [14]; an up-to-date overview with detailed test protocols can be found in Zou et al. 2016 [15]).

\section{Work-related olfactory dysfunction}

The prevalence of olfactory dysfunction in the wider population is estimated at around 5\% (for functional anosmia) [16]. It is considerably more common among older people, and around a quarter of the population aged over 50 exhibit an impaired sense of smell. The results of recent studies suggest that specific anosmias, the failure to sense a specific odour, are far more prevalent than was previously assumed and are the norm rather than the exception [16, 17]. The proportion of olfactory dysfunction caused by occupational exposure remains unclear. Figures for olfactory dysfunction caused by exposure to the effects of chemicals and pharmaceuticals fluctuate between 0.5 and $5 \%$ of all cases [18]. According to a large-scale survey of all ear, nose and throat clinics in the German-speaking world, covering 79,000 patients, $2 \%$ of the cases had toxic causes [19]. A recent Belgian publication covering a substantially smaller collective of 496 patients with exclusively non-sinusoidal complaints from a specialist clinical centre assumed that $3.4 \%$ were toxic in origin [20]. "Idiopathic" cases of olfactory dysfunction, which are put at between 10 and 25\%, may however include cases of chemically induced damage caused by workplace exposure not classified as such [21, 22]. In his paper on functional testing and dysfunction of olfaction, Herberhold [23] assumed several decades ago that pathologically elevated olfactory thresholds were present in around $30 \%$ of workers in the metals and chemical industry, possibly rising to around $50 \%$ with increasing age and increasing duration of exposure to the hazardous substances. Today's working conditions and exposures are clearly not comparable with those of the 1970s; in her review however, Dalton 2010 [24] also cites a questionnaire and survey conducted in 1995 among 712,000 individuals in Canada and the USA which revealed that factory workers of all ages reported a weaker sense of smell and performed significantly worse in an olfactory test than members of other occupational groups. 
According to Herberhold [23], thermal, mechanical and chemical noxae may lead to olfactory dysfunction, the effects triggered by chemicals being more pronounced the more active the chemical substance, the smaller the particles, and the longer the duration of exposure of the sensory apparatus to them. Occupational exposure to numerous industrial chemicals, notably those that are irritative and corrosive to the mucous membranes or harmful to the nerves, is associated with the incidence of olfactory dysfunction (see for example Klimek et al. 1999 [25] and Muttray et al. 2006 [26]). In his overview, Amoore [27] lists over 100 substances presumed capable of causing olfactory dysfunction. This information is based almost entirely upon case reports rather than on large-scale studies. The discussion below therefore gives consideration to the substances associated with occupational olfactory dysfunction that have been studied under standardised conditions in epidemiological studies and studies of test subjects. The results of relevant animal experiments concerning the substances identified in this way that to some extent permit conclusions regarding the possible mechanism of action are also presented.

\section{Industrial chemicals with a potential impact upon olfaction}

In order to identify industrial chemicals exposure to which may potentially lead to olfactory dysfunction, a literature survey was conducted in the Pubmed database in order to identify substances characterised as olfactotoxic primarily on the basis of epidemiological studies and studies of test subjects conducted under standardised conditions. The terms "anosmia", "hyposmia", "dysosmia", "smell disorders", "olfactory function", "olfactory dysfunction" and "olfaction disorders" were each combined in the search with "occupational", "professional" and "workplace". In the second step, the substances identified in this way were used as search terms in combination with the relevant clinical pictures (see above) in order to identify animal experiments. Relevant studies in the bibliographies of the identified literature were considered. Pharmacological and environmental studies associated with the identified industrial chemicals were also included. Case reports, for example concerning accident-type events involving very high exposures, were disregarded.

A comprehensive overview of long-term effects of occupational exposures to metals and olfactory toxicity can be found in the reviews by Gobba 2006 and Sunderman $2001[21,28]$. One aspect addressed by the recent review in Doty 2015 is likewise the influence of exposure to neurotoxic substances in the environment or at the workplace upon the sense of smell [4]. Accordingly, the studies referred to in these publications will not be considered in further detail in the present paper. The focus here lies on the epidemiological and animal studies not stated there. The latter will be described in detail.
Human studies on olfactotoxic effects caused by chemicals are summarised in Table 1.

\section{Cadmium and nickel}

A considerable number of epidemiological studies demonstrate an association between exposure to metals in the form of dusts and vapours, and occupational olfactory dysfunction. Anosmia and hyposmia were diagnosed for example among workers exposed to dust containing nickel or cadmium in plants for the production of alkaline batteries, nickel refineries, and the cadmium industry.

\section{Human studies}

Cadmium exposure Nine epidemiological studies published in the period from 1950 to 2003 [29-37] address the association between workplace cadmium/nickel exposure and olfactory impairment. The older studies lack clear information on the test methods and comparisons with non-exposed subjects [29-32]. Anosmia/hyposmia was detected in a significantly high proportion of the exposed workers in all human studies. Differentiated sensory and identification tests were conducted in three studies [34-37]; Rydzewski et al. and Sulkowski et al. $[35,36]$ describe the same data, which can therefore also be counted as one. Whereas Rose et al. and Mascagni et al. [34, 37] demonstrated that the values obtained in the sensory threshold test were considerably higher among the workers than in the control group, the identification test revealed no significant differences. The sensory threshold test for n-butanol or phenyl ethyl alcohol is regarded as an instrument for diagnosing the function of the peripheral olfactory receptor neurons. According to this interpretation, the ability to identify odours is based primarily upon the processing of olfactory information in the cerebral cortex. This absolute distinction is problematic however, since the sensory threshold test also encompasses complex functions of the central nervous system, and the identification of odours is dependent upon the activity of the olfactory receptor neurons.

Many of the epidemiological studies that describe the incidence of olfactory dysfunction following exposure to cadmium are older. In the 1950s and 1960s, occupational exposure to cadmium was appreciably higher than it is today, for example $0.6-236 \mathrm{mg} / \mathrm{m}^{3}$ in a battery factory [31]. The threshold limit values (TLVs) proposed by the American Conference of Governmental Industrial Hygienists (ACGIH) stated a limit concentration of $50 \mu \mathrm{g} / \mathrm{m}^{3}$ in 1975 and $10 \mu \mathrm{g} / \mathrm{m}^{3}$ as of 1995. Conversely, more recently published measured exposure values of $0.004-0.187 \mathrm{mg} / \mathrm{m}^{3}$ [32], $0.3 \mathrm{mg} / \mathrm{m}^{3}$ [34] and $1.53 \mathrm{mg} / \mathrm{m}^{3}$ (1975) and $0.0171 \mathrm{mg} / \mathrm{m}^{3}$ (1995) [37] demonstrate that damage to olfactory function may arise even at low concentrations. 


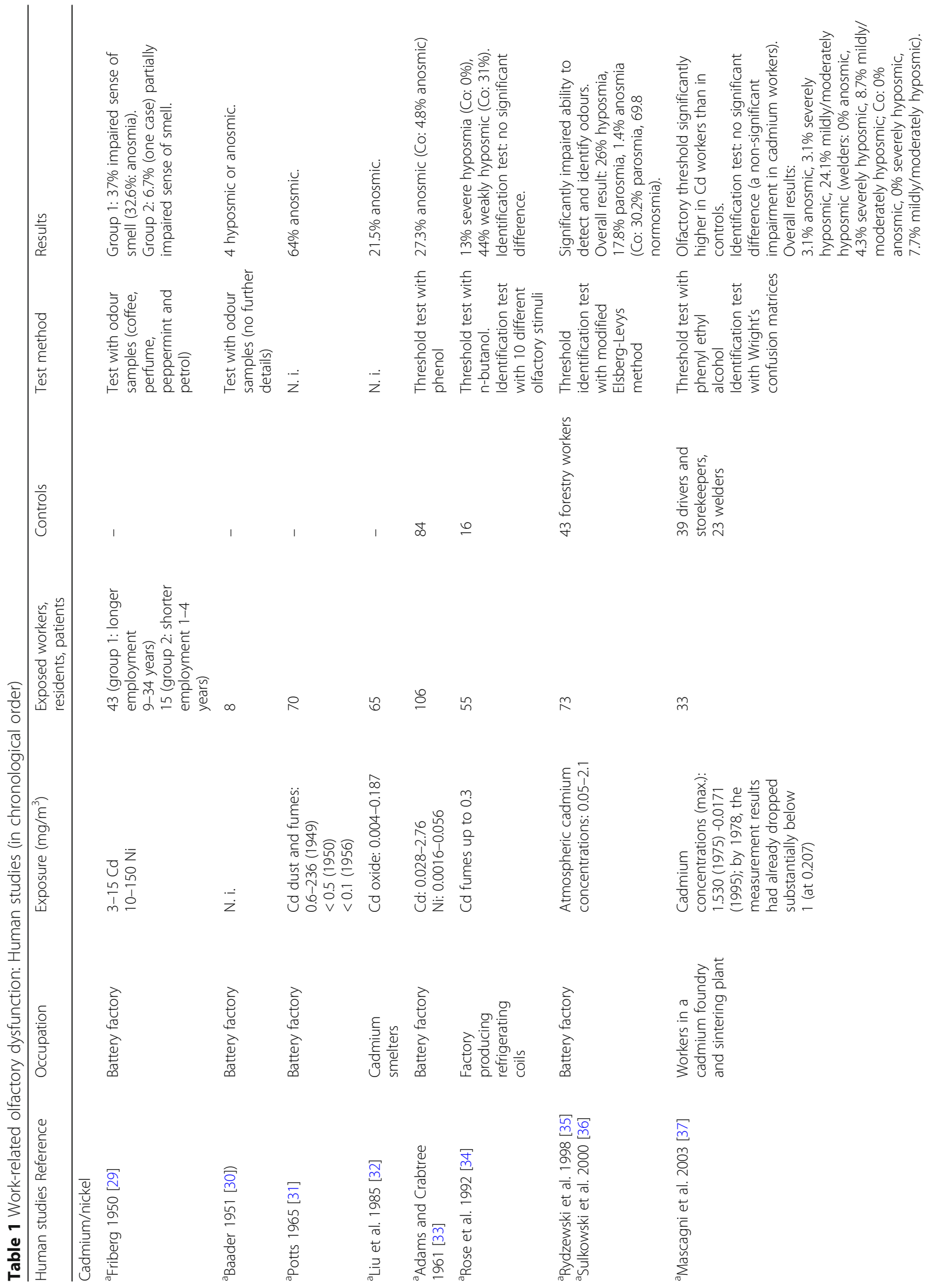




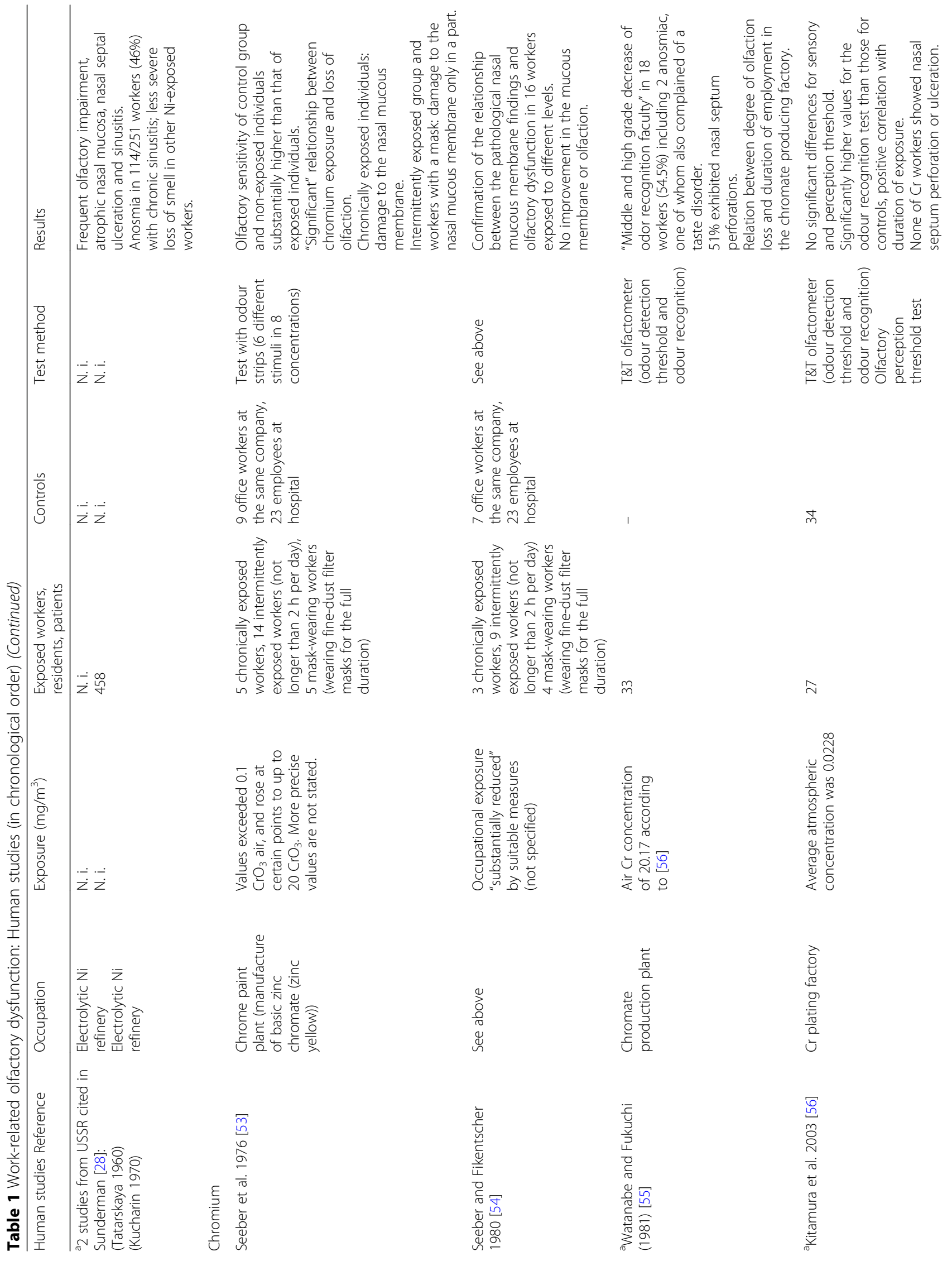




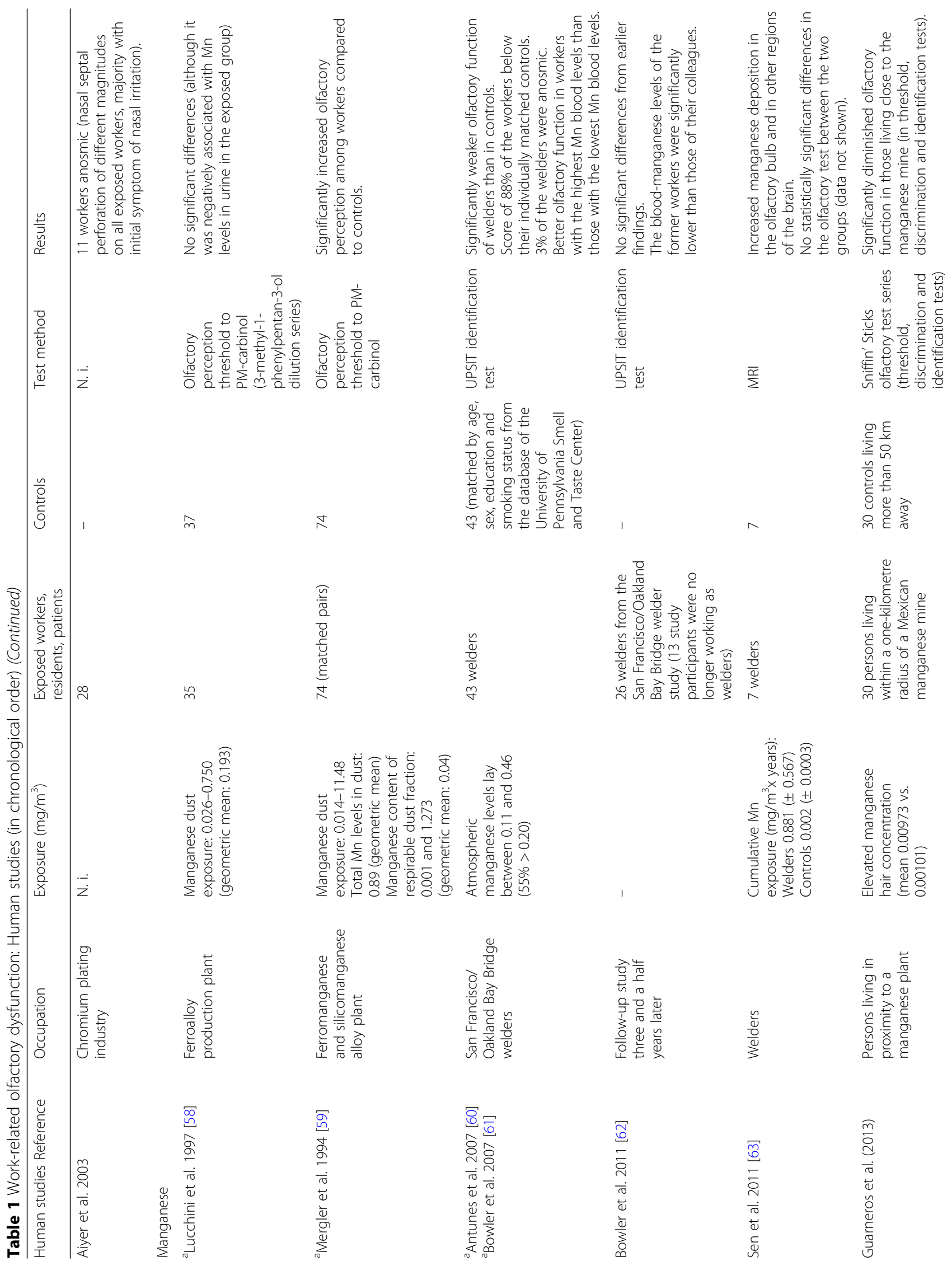




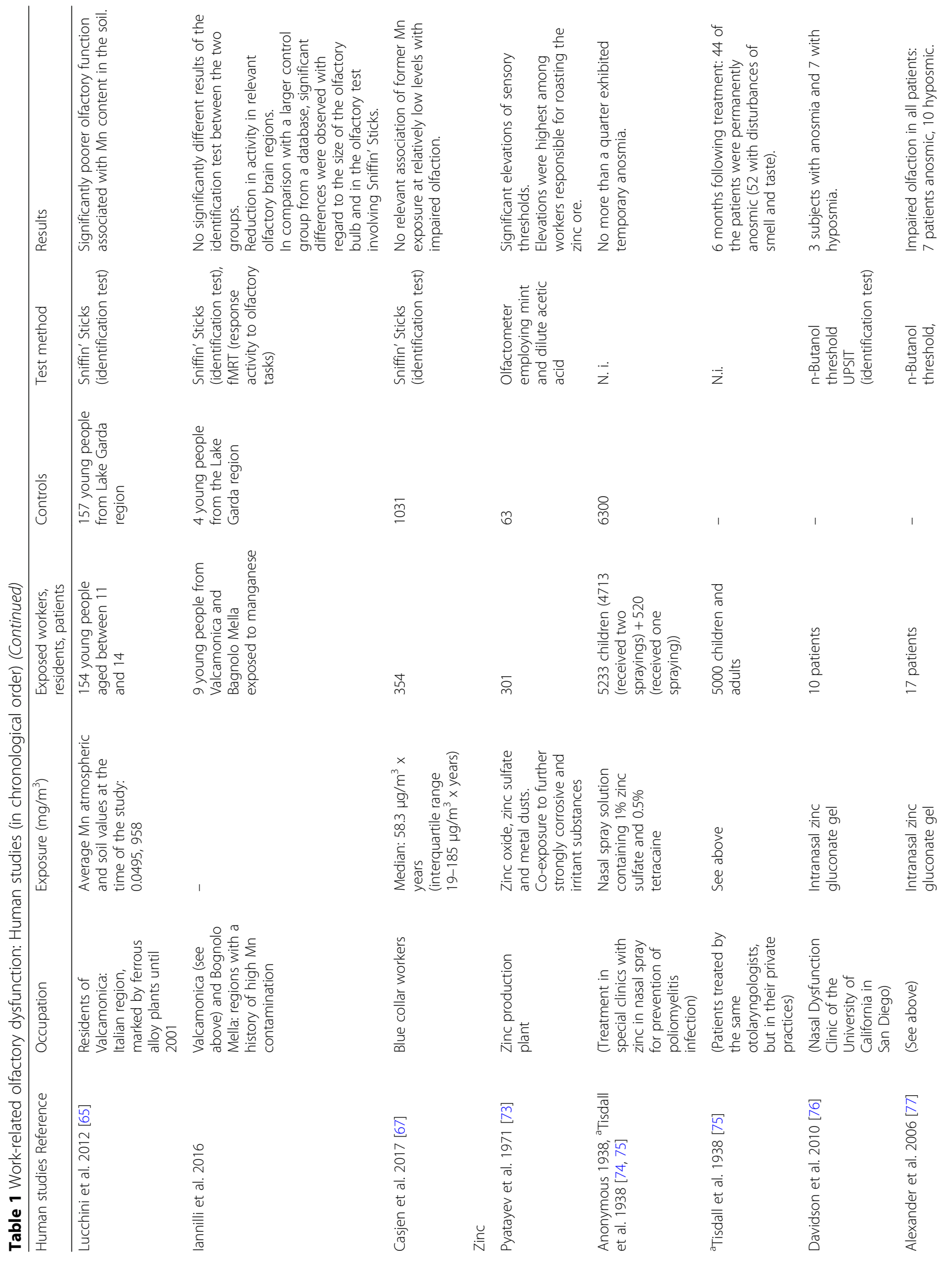




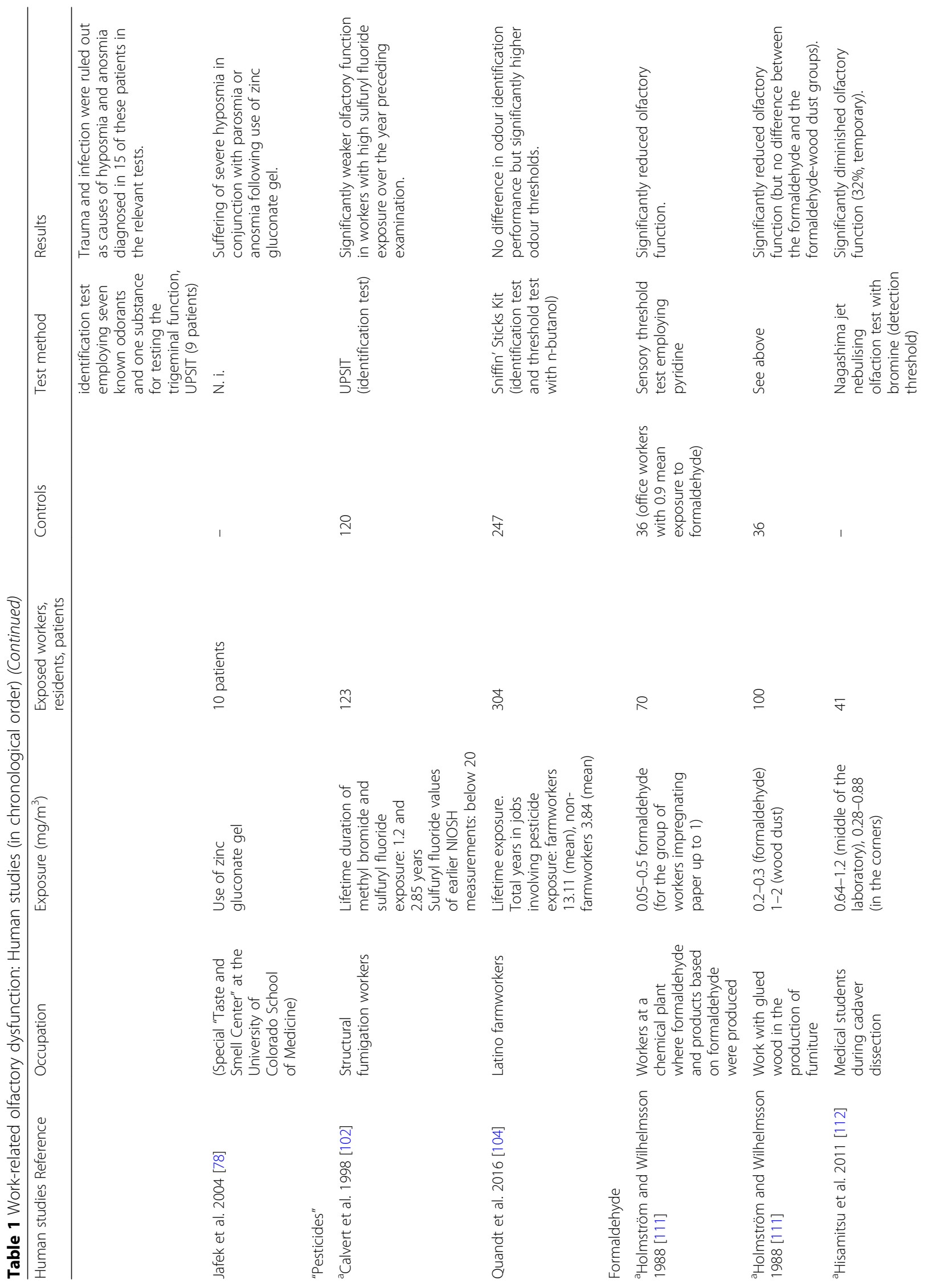




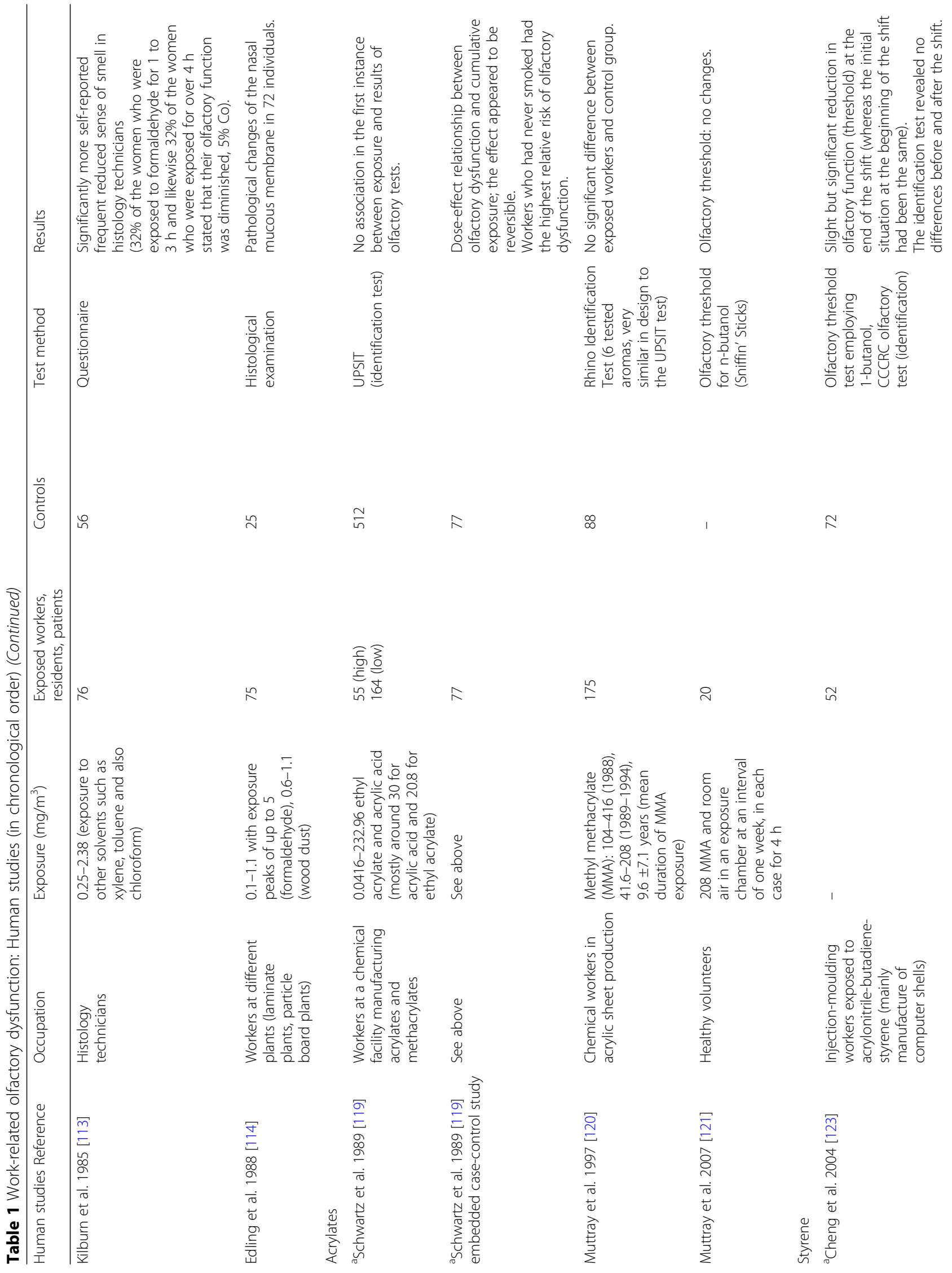




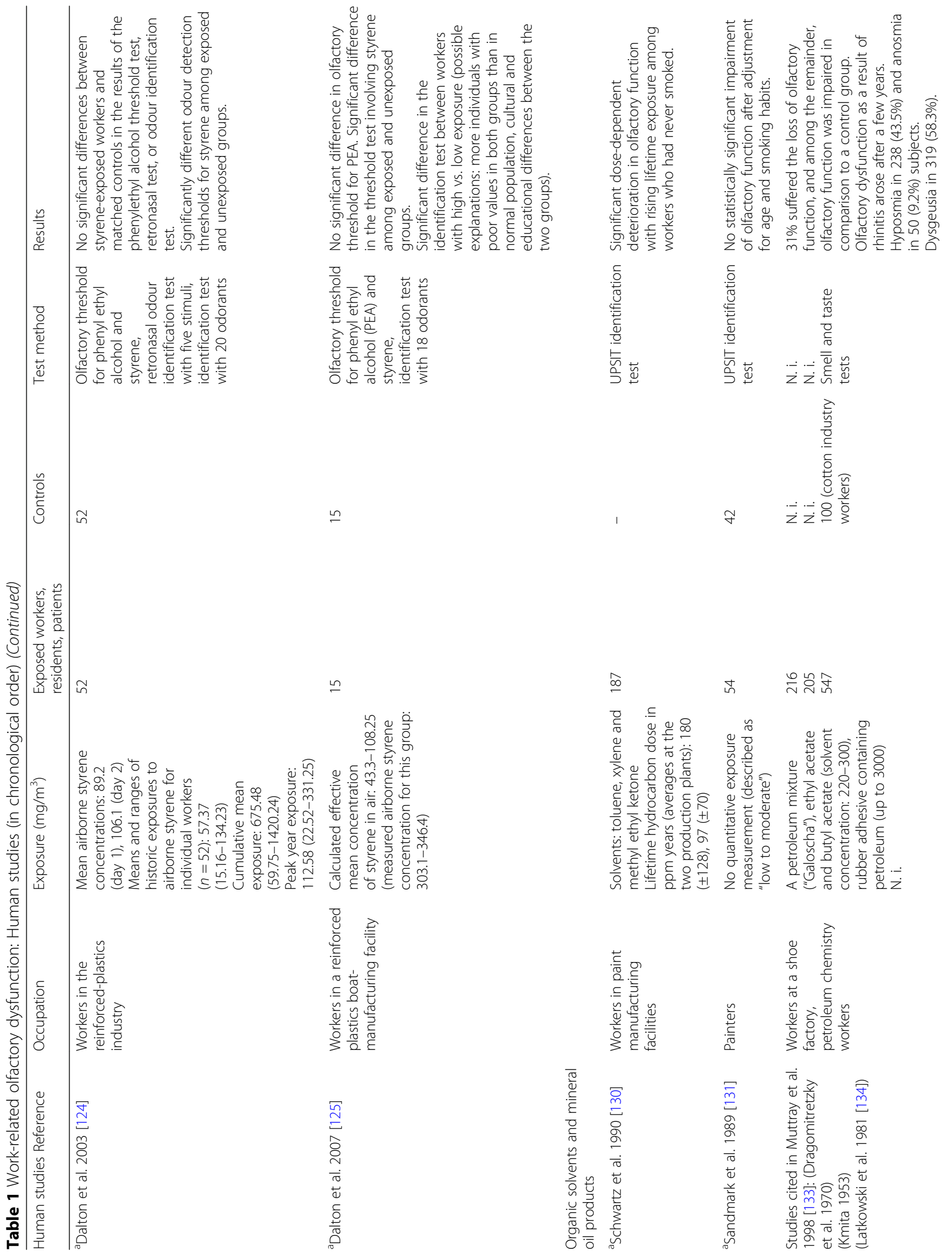




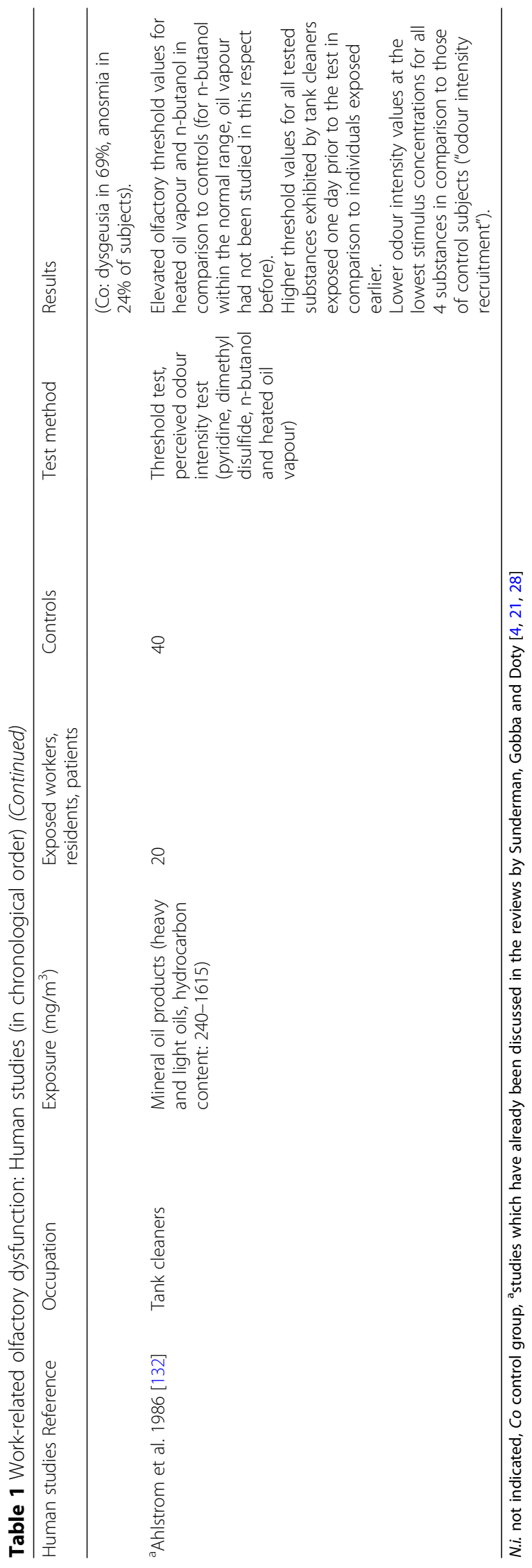


Nickel exposure With the exception of the studies stated by Sunderman, we are not aware of any studies into the association between workplace nickel exposure and olfactory dysfunction. Sunderman [28] cites two studies from the former Soviet Union from 1960 and 1970, according to which workers exposed to nickel in electrolytic nickel refineries exhibited olfactory dysfunction/anosmia in addition to atrophy of the nasal mucous membrane, chronic sinusitis and ulceration of the nasal septum.

In the studies cited concerning cadmium, the workers were often exposed not only to cadmium, but also to nickel (see above). Whereas in the 1940s, occupational nickel exposure of $10-150 \mathrm{mg} / \mathrm{m}^{3}$ for example was possible [29], considerably lower values of up to $0.056 \mathrm{mg} /$ $\mathrm{m}^{3}$ were measured in the publication by Adams and Crabtree in 1961 [33]. ACGIH currently sets a TLV of $1.5 \mathrm{mg} / \mathrm{m}^{3}$ for the inhalable fraction of nickel.

\section{Animal experimental studies}

Cadmium exposure Following inhalation tests on rats (250 and $500 \mu \mathrm{g} / \mathrm{m}^{3} \mathrm{CdO}, 5 \mathrm{~h}$ per day, 5 days per week for 20 weeks), an elevated cadmium level was determined in the olfactory bulb. This was accompanied neither by significant histopathological changes in the mucous membrane, nor by a reduction in the olfactory function [38].

In another animal experiment, administration of $400 \mu \mathrm{g}$ of $\mathrm{CdCl}_{2}$ to mice by intranasal instillation resulted in partial damage to the olfactory epithelium, reversible loss of olfactory discrimination, and specific cadmium deposition in the olfactory bulb but not in other parts of the central nervous system [39]. Czarnecki et al. [40] also observed anosmia in a behavioural test following intranasal instillation of a cadmium chloride solution in mice. They further demonstrated a dose-dependent reduction in the odour-induced release of neurotransmitters from the olfactory nerve into the olfactory bulb. Moreover, a $20 \%$ drop in the dendrite density of the olfactory epithelium was described at the highest dose $(20 \mu \mathrm{g} \mathrm{CdCl} 2)$. In further experiments, Czarnecki et al. demonstrated a clear cadmium accumulation on mice specifically in the olfactory bulb by bilateral instillation of a buffer solution of $20 \mu \mathrm{g}$ of $\mathrm{CdCl}_{2}$ per nostril. The accumulation was still measurable 4 weeks after exposure. A reduction in the axonal terminals of the olfactory receptor neurons was also demonstrated histologically. A decrease in neurotransmitter release in response to olfactory stimulation was detected in vivo on the mice exposed to cadmium (intranasal instillation with 0.2, 2 and $20 \mu \mathrm{g} \mathrm{CdCl}_{2}$ ) 2, 7 and 28 days after exposure. After the laboratory animals treated with cadmium had exhibited significant olfactory deficits in a behavioural test, these deficits disappeared after two weeks of olfactory training; however, the mice with restored olfaction continued to exhibit damaged projections of the olfactory receptor neurons in the results of optical imaging. Czarnecki et al. conclude from this that restoration of olfactory function is attributable to neuroplasticity: the brain, they assume, has learnt to reinterpret the reduced stimuli appropriately. Such processes of neuronal plasticity could mask severe damage by neurotoxic substances [41].

Cadmium-induced olfactory impairment was also confirmed in fish [42]: after 8-h exposure to $347 \mathrm{ppb}$ of $\mathrm{Cd}$ in fresh seawater, coho salmon exhibited not only histological changes to the olfactory epithelium and diminished olfaction in the behavioural test (for example loss of the tonic immobility response to olfactory alarm signals), but also significantly reduced expression of olfactory receptors and increased expression of enzymes involved in the antioxidant reaction in relation to metals. During 48-h exposure to $3.7 \mathrm{ppb}$, tonic immobility responses were diminished and histological changes to the olfactory epithelium likewise occurred that were not as pronounced as in the highly exposed fish group.

Nickel exposure Inhalation of $\mathrm{NiSO}_{4}(0.635 \mathrm{mg}, 6 \mathrm{~h}$ per day, 16 days) caused atrophy of the olfactory epithelium in rats, $\alpha-\mathrm{Ni}_{3} \mathrm{~S}_{2}$ additional chronic inflammation of the nasal tissue. Significant impairment of olfaction was not recorded [43-47]. Studies on rats and apes confirm the transport of nickel into the olfactory bulb following inhalation of soluble $\mathrm{NiSO}_{4}$ [47]. Following intranasal instillation of ${ }^{63} \mathrm{Ni}^{2+}$ in rats, the uptake pathway was tracked from the olfactory epithelium, via the axons of the primary olfactory neurons, into the glomeruli in the olfactory bulb and into further parts of the brain [48]. A maximum ${ }^{63} \mathrm{Ni}^{2+}$ transport rate of $0.13 \mathrm{~mm} / \mathrm{h}$ was measured in the olfactory neurons of pike [49]. In a recent examination by Jia et al. [50], intranasal instillation of nickel sulfate $(0.5$ and $2.5 \mathrm{mg} / \mathrm{kg})$ in mice led to dose-dependent and time-dependent atrophy of the olfactory epithelium of the turbinate bone, but not of the septum. The sustentacular cells were affected first by apoptotic cell loss on the first day post exposure, the olfactory receptor neurons on the third day; a significant increase in cell proliferation in the olfactory epithelium was detected after 5 to 7 days.

Neuronal signal transduction by calcium and apoptosis is a factor in olfactory impairment by nickel: according to Zhao et al. [51], $\mathrm{NiSO}_{4}$ is capable of inducing apoptosis by activation of the death receptor 3 and caspase- 8 and subsequent activation of caspase-3; Jia et al. suspect $\mathrm{NiSO}_{4}$-induced apoptosis of the olfactory receptor neurons to be attributable to this mechanism. Moreover, according to Gautam et al. [52], $\mathrm{Ni}^{2+}$ can reduce the odour-induced calcium influx by inhibition of the T-type 
$\mathrm{Ca}^{2+}$ channels in the olfactory receptor neurons, thereby impairing signal transduction.

\section{Chromium \\ Human studies}

Exposure to chromium is frequently encountered in combination with nickel and other metals. According to Seeber et al. [53], ulcers on the skin and mucous membrane and perforation of the nasal septum caused by chromium were known as long ago as 1826 . Few epidemiological studies exist of a possible association between chromium exposure and olfactory dysfunction.

In all 5 human studies known to us, deficits in the olfactory function of the exposed workers were detected that were associated significantly with the chromium exposure and the duration of employment [53-57]. The study by Seeber et al. and the follow-up research by Seeber and Fikentscher of 1976 and 1980 were not mentioned in the reviews by Gobba, Sunderman and Doty, and are described accordingly in more detail here: Seeber et al. (1976) and Seeber and Fikentscher (1980) reported on damage to the nasal mucous membrane and olfactory dysfunction among workers at a chrome paint plant in the German Democratic Republic (GDR) in which basic zinc chromate (zinc yellow) was manufactured [53, 54]. In their comparison between chronically exposed workers (5), intermittently exposed workers (14, not longer than $2 \mathrm{~h}$ per day), mask-wearing workers (5, wearing fine-dust filter masks for the full duration), non-exposed individuals ( 9 office workers at the same company) and a control group (23 employees at a hospital), they determined by means of rhinoscopic examinations that damage to the nasal mucous membrane was evident on all five of the chronically exposed individuals, but occurred only in a part of the intermittently exposed group and among the workers wearing masks, and not at all in the other groups. Olfactory tests involving odour strips for ascertaining the sensitivity to certain substances showed the olfactory sensitivity of the control group and the non-exposed individuals to be substantially higher than that of the exposed individuals. The authors considered this relationship between chromium exposure and loss of olfaction to be "significant". According to the authors, the dust values measured at the points at which zinc chromate dust was produced clearly exceeded the occupational exposure limit for chromium (VI) applicable in the GDR at this time of $0.1 \mathrm{mg} \mathrm{CrO}_{3} /$ $\mathrm{m}^{3}$ air, and rose at certain points to up to 200 times the occupational exposure limit. More precise values are not stated. Four years later, after violation of the occupational exposure limit in this plant had been "substantially reduced" by suitable measures (not specified), the workforce was examined once again. It was found that in 16 workers exposed to different levels, the relationship between the pathological nasal mucous membrane findings and olfactory dysfunction was confirmed, and that on average, no improvement in the mucous membrane or olfaction was detected [54].

Besides the results obtained by Watanabe and Fukuchi (1981) and Kitamura et al. (2003), in which an impaired olfactory function in workers in the chromate and galvanising industry was detected by means of the T\&T olfactometer and which have already been described in detail in Gobba 2006, workers in galvanising are also shown to be affected by olfactory dysfunction in an Indian publication from 2003: the authors reported on 28 workers in the chromium industry aged between 22 and 37 and exposed to chromium for between 5 and 14 years. Of these, all 28 employees exhibited nasal septum perforations, and 11 were anosmic. Information on the level of exposure and on the test method was not provided [57].

Kitamura et al. reported chromium-induced olfactory dysfunction at low workplace concentrations [56]. The exposure values for chromium measured in this study were 0.0047 to $0.059 \mathrm{mg} / \mathrm{m}^{3}$. ACGIH set a TLV of $0.05 \mathrm{mg} / \mathrm{m}^{3}$ for water-soluble $\mathrm{Cr}$ (VI) compounds and $0.01 \mathrm{mg} / \mathrm{m}^{3}$ for insoluble $\mathrm{Cr}(\mathrm{VI})$ compounds.

\section{Animal experimental studies}

In his review of the relationship between exposure to metals and nasal toxicity, Sunderman cites an animal experiment on rats. Following 40 days' inhalation of sodium dichromate $\left(0.2 \mathrm{mg} / \mathrm{m}^{3}, 6 \mathrm{~h}\right.$ per day, 40 days $)$, the rats exhibited no morphological nasal changes. Olfaction was not tested [28].

\section{Manganese}

\section{Human studies}

According to the results of our searches, 10 human studies are available to date that examine the association between manganese exposure and impairment of the sense of smell [58-67]. The study populations encompass not only exposed workers, but also persons living close to a manganese mine and young people living in a region in which manganese emissions of industrial origin were very high prior to 2001. In the two studies conducted on workers in the metals industry $[58,59]$, in which only the sensory test method was employed, the results were either not significant [58] or, surprisingly, revealed a significantly increased olfaction perception among the workers in measurements of the sensory olfactory threshold [59]. By comparison, use of the olfactory identification test employing Sniffin' Sticks on welders or the inhabitants of an area with elevated background manganese values revealed significantly poorer values [60-62, 64-66]. In further magnetic or functional resonance imaging studies, elevated manganese deposition in the olfactory bulb was 
measured on welders [63] and a reduction in activity in relevant olfactory brain regions was measured in young people living in a region exhibiting elevated manganese values [66].

The following recent studies have not yet been discussed in the reviews by Sunderman, Gobba and Doty and will therefore be presented in more detail here:

In a follow-up survey, 26 welders who had participated in the San Francisco/Oakland Bay Bridge welder study $[60,61]$ were examined three and a half years later by the same methods. Although 13 participants were no longer working as welders, the results obtained in the UPSIT did not differ significantly from the earlier findings. The blood-manganese levels of the workers who were no longer welding were significantly lower than those of their colleagues [62].

For seven welders, increased manganese deposition in the olfactory bulb and in other regions of the brain was demonstrated by means of functional magnetic resonance tomography [63].

Guarneros et al. (2013) conducted a Sniffin' Sticks olfactory test series encompassing threshold, discrimination and identification tests on persons living in proximity to a manganese plant and exhibiting an elevated manganese concentration (mean $9.73 \mu \mathrm{g} / \mathrm{g}$ vs. $1.01 \mu \mathrm{g} / \mathrm{g}$ ) in their hair [64]. Significant differences between the subjects were observed. In this study, 30 persons (non-smokers) living within a one-kilometre radius of a Mexican manganese mine were compared with 30 controls living more than $50 \mathrm{~km}$ away. The groups were matched by age, sex and school education; none had previously worked in a job involving manganese exposure. The results of the Sniffin' Sticks test revealed substantially diminished olfactory function in those living close to the manganese mine.

By means of the identification test employing Sniffin' Sticks, Lucchini et al. also documented significantly poorer olfactory function associated with the Mn content in the soil on 154 young people aged between 11 and 14 in Valcamonica (Italy). Up until 2001, this region was marked by ferrous alloy plants and the emissions from them (average $\mathrm{Mn}$ atmospheric and soil values at the time of the examination: $49.5 \mathrm{ng} / \mathrm{m}^{3}$ and $958 \mathrm{ppm}$ respectively). Young people from the region around Lake Garda were tested as the control group [65]. In a further study employing functional magnetic resonance tomography, the activity of the brain in 9 young people from Valcamonica and Bagnolo Mella exposed to manganese was compared with that of 4 young people from the Lake Garda region. In the exposed young people, a reduction in activity in relevant olfactory brain regions was detected, for example in the orbitofrontal cortex and piriform cortex and in further brain regions typically associated with olfactory function, such as the middle frontal gyrus and cerebellum. In comparison with a larger control group from a database, significant differences were also monitored with regard to the size of the olfactory bulb and in the olfactory test involving Sniffin' Sticks. Reduced activity in comparison with that of the controls was also noted in the regions of the limbic system [66].

In a recent prospective cohort study, Casjens et al. examined the influence of work-related manganese exposure upon the olfactory function. The study population comprised 1385 men, of whom 354 had potentially been exposed to manganese in their earlier occupations. No relevant association was determined between manganese exposure and a deterioration in olfactory function [67].

\section{Animal experimental studies}

Experiments on pikes and rats showed that following intranasal application of a dilute ${ }^{54} \mathrm{MnCl}_{2}$ solution, manganese is absorbed by the olfactory epithelium and transported on into the brain. In the process, manganese accumulates in the olfactory bulb and can be detected after 12 weeks throughout the brain and spinal cord [68-71]. Transport of the manganese from the nasal cavities into the brain requires the axonal projections of the olfactory epithelium's receptor neurons to be intact [72]. Foster et al. also evaluated the transport of manganese from the olfactory epithelium to the olfactory bulb: a bilateral instillation of $40 \mu \mathrm{l} 200 \mathrm{mM} \mathrm{MnCl} 2$ in rats leads to an increase in manganese levels in both the olfactory epithelium and the olfactory bulb, and the rats exposed to manganese exhibit decreased performance in the olfactory discrimination task. Manganese accumulation in the olfactory bulb and in other regions of the brain was also demonstrated by MRT studies on non-human primates exposed to aerosolised $\mathrm{MnSO}_{4}(\geq$ $0.06 \mathrm{mg} \mathrm{Mn} / \mathrm{m}^{3}$ ) [71].

\section{Zinc}

Exposure to zinc in the form of fumes and dust frequently occurs during the manufacture and processing of metals. With the exception of one study published in 1971 in Russian [73], we are not aware of any studies of a possible relationship between the incidence of olfactory dysfunction and occupational zinc exposure. Studies do exist of the frequent incidence of anosmia following medical intranasal application of sprays or gels containing zinc, as do studies on animals demonstrating an association between intranasal exposure to zinc salts and adverse influence upon olfactory function [74-94].

\section{Human studies}

In 1971, 301 workers at a zinc production plant were examined with regard to their olfactory and trigeminal 
function and compared with a control group comprising 63 workers at a machine factory [73]. The olfactory tests were performed by means of an olfactometer employing mint and dilute acetic acid (trigeminal stimulation). In comparison with the sensory threshold values of the control group the sensory thresholds of the exposed workers were statistically significantly elevated. The elevations were highest among the workers responsible for roasting the zinc ore. High concentrations - according to the author several times higher (without closer specification) than the limits in force at the time - of further strongly corrosive and irritant substances such as sulfur dioxide, sulfur anhydride, sulfuric acid, chlorine, hydrogen fluoride and others were however released in all three working areas (roasting, leaching, electrolysis) covered by the study, besides zinc oxide, zinc sulfate and metal dusts. Assessing the impact upon health to a particular substance is therefore difficult.

The link postulated by Seeber and Fikentscher between the effects of olfactory impairment observed among workers in a zinc chromate plant and exposure to chromium may perhaps equally be associated with zinc. This possibility was not examined in these studies [53, 54].

The suspicion that zinc in the form of a pharmaceutical component was capable of triggering olfactory dysfunction dates back to the 1930s. The suitability of a solution containing $1 \%$ zinc sulfate and $0.5 \%$ tetracaine (a topical anaesthetic) for use as a nasal spray for prevention of poliomyelitis infection was studied in Toronto in 1938 [28]. It was found not only that the desired protection was not achieved, but that some children and adults also developed anosmia. According to reports by the British Medical Journal and the Journal of Pediatrics, of 5233 children (for the most part aged between 3 and 10) treated in special clinics by otolaryngologists, approximately a quarter exhibited temporary anosmia [74, 75]. Unfortunately, the documentation contains no description of the diagnostic method, quantitative details of temporary and permanent olfactory dysfunction, or any indication whatsoever of systematic olfaction testing in the control group [74, 75]. Information on the control group and the test method were relevant insofar as recent studies indicate that olfaction is poorer in children than in adults: in the study by Sorokowska et al. of 1422 test subjects (aged between 4 and 80), children aged under 10 and adults aged over 70 performed worst in an identification test involving Sniffin' Sticks with 16 different odours [95]. Tisdall et al. (1938) were in possession of data from a collective of an estimated 5000 further patients (children and adults) treated with zinc sulfate of which 44 were permanently anosmic as a consequence of the treatment. However, in this collective the 44 patients identified as having permanent olfactory dysfunction accounted for fewer than $1 \%$, which is below the estimated figure for olfactory dysfunction in the wider population $[16,96]$.

Olfactory dysfunction occurring in patients following intranasal use of Zicam gel, claimed by the manufacturer to be "homeopathic" (according to Mossad, Zicam nasal gel contains $33 \mathrm{mmol} / \mathrm{l}$ zinc gluconate [97]) for prophylactic or therapeutic purposes against the symptoms of colds, was documented by Davidson and Smith, Alexander and Davidson, and Jafek et al. [76-78].

In 2009, the US Food and Drug Administration (FDA) issued warnings to consumers against three intranasal "Zicam" products containing zinc owing to the suspicion that they "may cause a loss of sense of smell", possibly permanent [98]. The products concerned were then taken off the market in 2009.

The possible olfactory effect of a nasal insulin spray containing zinc as an additive was also the subject of recent discussion $[99,100]$. Indeed, it is unclear how much of the zinc spray actually reaches the olfactory cleft. Notable in this context are the results of experiments by Herranz Gonzalez-Botas and Padin Seara, who examined the efficacy of the nasal gel form of application and ascertained that pigmented nasal gel is not detectable in the olfactory cleft following self-application by 16 test subjects [101].

\section{Animal experimental and in vitro studies}

The cytotoxic effect of Zicam was also demonstrated in vivo on mice and in vitro on human nasal tissue. Following instillation of Zicam by injection in the nasal cavities (15 $\mu$ l per cavity), the olfactory epithelium was especially affected. The results of the behavioural test showed that treatment of the mice with Zicam led to olfactory dysfunction that still persisted two months after treatment. In the human nasal tissue samples, necrosis of the epithelial and subepithelial structures was observed following the application of Zicam [80].

Numerous further histological studies have been performed that illustrate the degenerative effect of zinc salts upon the olfactory epithelium in mice and fish [81-86]. Several studies in which $\mathrm{ZnSO}_{4}$ is used for experimental induction of anosmia in laboratory animals demonstrate that direct treatment of the olfactory mucous membrane with zinc sulfate solution impairs olfaction in mice, rats, hamsters and pigeons [81, 84, 87-91]. McBride et al. (2003) provide an overview of 22 behavioural studies on mice in which olfactory dysfunction was induced by means of intranasal irrigation with $\mathrm{ZnSO}_{4}$ [81].

Following intranasal zinc gluconate instillation on mice (33 mM, 50-100 $\mu \mathrm{l}$ per nostril), Duncan-Lewis et al. (2011) were able to demonstrate, by means of a behavioural test, a significant reduction in olfaction compared to control mice treated only with phosphate-buffered 
saline (PBS) [92]. Significantly weaker olfaction was also exhibited by mice following treatment with copper gluconate. Irrigation with magnesium gluconate yielded no differences. The olfactory dysfunction was reversible, since no differences in olfactory behaviour were observed in a further behavioural test performed one month after treatment.

Electroolfactograms and patch-clamp tests on isolated rat olfactory epithelia showed that exposure to zinc metal nanoparticles in the picomolar range had a significantly reinforcing effect upon the reaction of the olfactory neurons following olfactory induction, whereas $\mathrm{Zn}^{2}$ ${ }^{+}$ions in the same concentration led to a reduced response to olfactory stimulation [93].

The toxic properties of zinc oxide nanoparticles in the olfactory system of rats are presented by Gao et al.: once-off instillation of a suspension of zinc oxide nanoparticles led to significant damage of the olfactory epithelium and to inflammation reactions [94]. In addition, the exposed rats exhibited a change in sniffing behaviour and appeared no longer able to distinguish between vanillin diluted with distilled water and distilled water alone. In an in-vitro assay on primary human olfactory cells, Osmond-McLeod et al. demonstrated that zinc oxide nanoparticles are able to induce cellular stress reactions, inflammation reactions and apoptosis, but do not activate DNA repair mechanisms [79]. They established that the cellular reactions to zinc oxide nanoparticles with a coated surface were weaker.

\section{"Pesticides"}

\section{Human studies}

As already reported by Doty the neurological functions of workers employed in structural fumigation involving the pesticides of methyl bromide and sulfuryl fluoride were compared in 2015 in a cross-sectional study with those of control persons [102]. Significantly weaker olfactory function tested with UPSIT was observed among the workers subject to high sulfuryl fluoride exposure. A corresponding observation was not made for the workers with high exposure to methyl bromide. It should be noted here that with the exception of 11 individuals, the majority of workers were subject to coexposure with methyl bromide. Clear distinction between the effects of methyl bromide and those of sulfuryl fluoride is therefore difficult, not least since division of the workers by the criteria of "high exposure to sulfuryl fluoride" and "high exposure to methyl bromide" is based upon statements made by the workers themselves in a questionnaire. Methyl bromide is highly toxic and harmful to the central nervous system. In animal experiments it also causes damage to the olfactory epithelium. According to the authors, further pesticides (including chlorpyrifos, organophosphates, carbamates, pyrethrins, organochlorine pesticides) with which the test subjects had come into contact during work or leisure revealed no significant association with the results of the olfactory test and the memory test involving patterns. During work, the fumigators were also exposed to "small amounts" of chloropicrin, which was used as an irritant warning substance during fumigation with sulfuryl fluoride and methyl bromide (no concentration stated). Chloropicrin is a highly irritant gas [103].

In one recently published study an impaired olfactory function was demonstrated in Latino farmworkers exposed to pesticides [104]. 304 farmworkers exposed to pesticides were compared with 247 non-farmworkers. At significantly greater self-reported lifetime pesticide exposure, the farmworkers required significantly higher concentrations for odour detection; the odour identification did not differ between the groups (Sniffin' Sticks). Unfortunately, it is not specified which types of pesticides the farmers worked with. In this context it is interesting that an impaired olfactory function could be an early symptom of Parkinson's disease (PD), and that pesticides are also suspected of inducing symptoms of Parkinson's. A strong association between farmers with a PD diagnosis and a reduced sense of smell is shown by Shrestha et al. 2017 [105].

\section{Animal experimental studies}

Whereas methyl bromide can strongly damage the olfactory epithelium in animal tests [106], the available literature provides no clear indication of the effect of sulfuryl fluoride upon olfaction. Inflammation of the nasal tissue was reported after high exposure to sulfuryl fluoride (inhalation of $300-600 \mathrm{ppm}$ ) in rats and rabbits [107, 108].

\section{Formaldehyde}

Olfactory dysfunction in humans caused by formaldehyde was described relatively early. Spealman [109] provides an indirect indication in that he cites the medical department of an airline that had rejected the use of deodorants containing formaldehyde in airliners on the grounds that formaldehyde was known to impair olfaction. Lehnhardt and Rollin mention the strange case of a company emergency response officer who developed anosmia allegedly owing to compulsive sniffing of a therapeutic agent that released formaldehyde [110].

\section{Human studies}

Four human studies involving formaldehyde and its association with olfactory dysfunction were identified [111-114].

In an epidemiological cross-sectional study by Holmström et al. of workers at a factory producing formaldehyde and formaldehyde-based products and workers exposed to both formaldehyde and wood dust, significantly reduced olfactory 
function was measured (sensory threshold test employing pyridine) [111]. Hisamitsu et al. demonstrated a significantly diminished olfactory function in medical students who were exposed to formaldehyde vapours during an anatomy course in Japan. It must be emphasised that all affected individuals already had a preexisting history of allergic rhinitis. Olfactory function was fully restored after a year [112]. The publications of Holmström et al. and Hisanitsu et al. [111, 112] are mentioned by Doty 2015 [4] and will not be presented in greater detail here.

Kilburn et al. describe the result of a survey involving 76 female histology technicians (average age 40.8) who were exposed to formaldehyde $(0.2-1.9 \mathrm{ppm})$ and to other substances such as xylene and toluene during their work with histological preparations [113]. 22 of these women were exposed to formaldehyde for 1 to $3 \mathrm{~h}, 47$ for over $4 \mathrm{~h}$. In a survey, 32\% of the women in each subgroup stated that their olfactory function was diminished. Among a control group of 56 non-exposed women (average age 39.5 ), this was stated by only $5 \%$.

A study of 75 male workers (average age: 38 ) with occupational exposure either to formaldehyde alone (0.1$1.1 \mathrm{mg} / \mathrm{m}^{3}$ with exposure peaks of up to $5 \mathrm{mg} / \mathrm{m}^{3}$ ) or to formaldehyde and wood dust $\left(0.6-1.1 \mathrm{mg} / \mathrm{m}^{3}\right)$ detected pathological changes of the nasal mucous membrane in 72 individuals [114]. No differences in the histological findings were observed between the workers exposed solely to formaldehyde and those who had also been exposed to wood dust.

Based upon the results of long-term toxicological inhalation studies on laboratory animals, an NOAEL for nasal damage of $1 \mathrm{ppm}$ formaldehyde was determined in the literature [115]. In their cross-sectional study, Holmström and Wilhelmsson observed a significant worsening of the sensory threshold even at formaldehyde concentrations below $0.37 \mathrm{mg} / \mathrm{m}^{3}$ ( $=0.3 \mathrm{ppm}$, and corresponding to the German OEL) [111]. Irreversible damage to the sensory tissue need not however be anticipated below the irritation threshold, upon which the OEL is based.

\section{Animal experimental studies}

Inhaled formaldehyde $(3.2 \mathrm{ppm})$ and acrylic aldehyde $(0.67 \mathrm{ppm})$ led to degeneration of the respiratory epithelium in rats, inhaled acetaldehyde (750 ppm) to degeneration of the olfactory epithelium. It was demonstrated on the same species of laboratory animal that the effects of a combined exposure to these aldehydes can increase exponentially [116].

10 rats were exposed for $4 \mathrm{~h}$ per day for 7 days to $12.5 \mathrm{mg} / \mathrm{m}^{3}$ formaldehyde by Li et al. [117]. Examination of the olfactory bulbs and hippocampi of the exposed rats revealed severe morphological damage compared to an untreated control group. Reduced production of glutamate, gamma-aminobutyric acid and nitrogen oxide synthase was also detected in this damaged tissue. Since the publication was in Chinese, only the English abstract could be evaluated here.

Diminished olfactory function was determined in rats that had been subject for $30 \mathrm{~min}$ twice a day for 14 days to inhalative exposure to a formaldehyde concentration of $13.5 \pm 1.5 \mathrm{ppm}$ [118].

\section{Acrylates \\ Human studies}

Gobba and Doty have already described the study by Schwartz et al. in their reviews: hundreds of workers were studied in a cross-sectional analysis at a factory producing acrylates and methacrylates [119]. The workers were divided into four classes according to their exposure. No association was established in the first instance between exposure and the results of olfactory tests (UPSIT, $p=0.09$ ). By means of an embedded case-control study, a dose-effect relationship was observed between olfactory dysfunction and cumulative exposure; the effect appeared to be reversible. The risk of developing olfactory dysfunction was greatest in the group of non-smokers.

Two studies were, however, not mentioned by Gobba or Doty:

In a cross-sectional study of 175 workers exposed to methyl methacrylate and a control group of 88 non-exposed workers employed in the same production unit for acrylic glass sheet casting, performance of the Rhino Identification Test ( 6 tested aromas, very similar in design to the UPSIT test) revealed only a single hyposmic case in the exposed group [120]. At 58.3\%, the proportion of smokers was higher in the exposed group than in the control group (34.1\%). Over an 8-h shift, exposure lay between 25 and $100 \mathrm{ml} / \mathrm{m}^{3}$ in 1988 and between 10 and $50 \mathrm{ml} / \mathrm{m}^{3}$ in the period from 1989 to 1994 . The average exposure duration was $9.6 \pm 7.1$ years. With the exception of 2 workers who were additionally exposed briefly to formaldehyde up to 1990 and 4 workers who additionally had contact with acrylonitrile, and a further 2 workers who were additionally exposed to both formaldehyde and acrylonitrile, all workers were exposed solely to methyl methacrylate. These results permit the conclusion that at exposures of up to $50 \mathrm{ml} / \mathrm{m}^{3}$ methyl methacrylate, olfactory function is not harmed.

In a more recent exposure study, 20 healthy male volunteers (non-smokers, aged 20-62) were exposed in an exposure chamber once to $49.2( \pm 1.4)$ ppm methyl methacrylate for $4 \mathrm{~h}$. Following exposure, no changes occurred in the olfactory threshold for n-butanol, which was measured by means of Sniffin' Sticks, nor had the measured mucociliary transit time (time from 
introduction of a saccharin particle in the lower nasal vestibule to perception of a sweet taste in the throat) changed. Also unchanged were the measured concentrations of protein and mRNA markers of inflammation in the nasal secretion and respiratory epithelium. Furthermore, only minor differences were observed in the mental state, which was evaluated by questionnaire. The authors concluded from this that acute exposure to $50 \mathrm{ppm}$ methyl methacrylate causes no inflammatory changes to the respiratory nasal mucous membrane, and that in view of the absence of a rise in the olfactory threshold following exposure to $50 \mathrm{ppm}$ methyl methacrylate, this dose is not sufficient to cause toxic damage to the olfactory epithelium. These results of acute exposure cannot be readily transferred to chronic conditions [121].

\section{Animal experimental studies}

Chronic exposure to $100 \mathrm{ppm}$ methyl methacrylate can cause degeneration and atrophy of the olfactory epithelium in rats. It must be considered that the activity of the carboxylesterase in the olfactory epithelium of the nasal mucous membrane is considerably higher in rats than in humans. The unspecific carboxylesterase hydrolyses methyl methacrylate to methyl acrylic acid, which is responsible for the local toxicity [122].

\section{Styrene}

\section{Human studies}

Three studies have already been listed by Doty [4]:

Cheng et al. [123] compared injection moulding workers exposed to styrene with non-exposed workers. At the end of a working day, a slight but significant reduction in olfactory function was detected in the olfactory threshold test employing 1-butanol, whereas the initial situation at the beginning of the shift had been the same. An identification test employing 7 odours (Connecticut Chemosensory Clinical Research Center (CCCRC) olfactory test) revealed no differences before and after the shift. According to Doty [4] these results support the "concept that the olfactory thresholds reflect adaptation rather than sustained neurological damage". Unfortunately, no exposure measurements were performed in this study.

Other epidemiological studies of workers in the glass fibre reinforced plastic industry revealed no relationship between styrene exposure and a general deterioration in olfactory function [124, 125]. In both studies the olfactory threshold for styrene was significantly higher among the exposed workers. According to Dalton et al., this is also explained by an adaptation effect, which leads to a reversible reduction in sensitivity. This has already been frequently observed for volatile substances in industry or the laboratory and is correspondingly well documented
[126]. Whereas the identification test revealed no differences between exposed and non-exposed individuals in the study published in 2003, the identification test published in 2007 resulted in a significant difference between the workers with high vs. low exposure [125]. Dalton et al. state that the proportion of individuals showing poor values in the identification test is substantially higher in both groups (40 and 20\%) than in the normal population (10\%) [125]. Even with the aid of multiple regression analysis, no association was demonstrated between the results of the identification test and the exposure values measured at present or in the past in the group of workers subject to high exposure. The authors therefore suspect that the high proportion of immigrants in the exposed group had influenced the results of the test, and they do not consider the results to be valid evidence of impairment of human olfactory function by workplace exposure to styrene.

\section{Animal experimental studies}

In two studies on rodents conducted in 1997 and 1998, already cited by Doty 2015, styrene exposure of between 20 and $50 \mathrm{ppm}$ led to lesions of the olfactory epithelium [127, 128]. Green et al. assumed that the nasal lesions induced in mice by exposure to styrene were caused by styrene oxide, which cannot be detected in the human nasal epithelium [129].

\section{Organic solvents and mineral oil products Human studies}

The publications by Schwartz et al. [130], Sandmark et al. [131] and Ahlstrom [132] are epidemiological studies evaluating a possible association between solvent exposure and impairment of olfaction. They are also cited by Gobba and Doty:

With consideration for smoker status, the UPSIT identification test performed by Schwartz et al. [130] yielded a significant dose-dependent deterioration in olfactory function of workers exposed to solvent in paint manufacture with rising lifetime exposure among workers who had never smoked. This effect was not observed among workers who had always smoked. The results remained the same when the confounders of age and cultural background (vocabulary testing) were taken into account. Schwartz et al. suspect that the induction of cytochrome P450 enzymes by cigarette smoke leads to an increase in the metabolism and thereby to detoxification of organic olfactotoxins before they reach the olfactory epithelium. The exposed workers who had always smoked performed worse in the UPSIT olfactory test compared to reference values, albeit not with dose dependency. The best olfactory function was exhibited by the workers with the lowest exposure who had never smoked. 
In an UPSIT identification test on painters, no impairment of olfactory function was observed following multiple regression analysis including consideration for age and smoker status [131]. Quantitative exposure measurement was not performed; the exposure was described as low to moderate. Tank cleaners studied by Ahlstrom et al. exposed to mineral oil products exhibited elevated olfactory threshold values for heated oil vapour and $\mathrm{n}$-butanol; these were still within the normal range for n-butanol. Oil vapour had not been studied in this respect before. To determine whether a relationship existed between the elevated threshold values and the interval between the most recent exposure and the olfactory test, the exposed workers were assigned to three groups with intervals of different duration (1 day to over 30 days) between exposure and the olfactory test. It was found that the tank cleaners who had been exposed just one day prior to the test exhibited higher threshold values for all tested substances than those who had not. A further test of the subjectively perceived odour intensity of all 4 substances tested (pyridine, dimethyl disulfide, n-butanol and heated oil vapour) revealed that at the lowest stimulus concentrations, the exposed persons exhibited lower odour intensity values than the control subjects [132].

Muttray et al. refer to one Russian and two Polish studies of the olfactotoxic effect of adhesives containing petroleum: of workers at a Russian shoe factory who had been exposed to an adhesive containing a petroleum mixture ("Galoscha"), ethyl acetate and butyl acetate (solvent concentration: 220$300 \mathrm{mg} / \mathrm{m}^{3}$ ), over $25 \%$ suffered atrophy of the nasal mucous membrane owing to inflammatory processes, $31 \%$ suffered the loss of olfactory function, and among the remainder, olfactory function was impaired in comparison to a control group [133]. Among 205 workers who used a rubber adhesive containing petroleum and were exposed to it up to a level of approximately $3000 \mathrm{mg} / \mathrm{m}^{3}$, olfactory dysfunction as a result of rhinitis arose after only a few years. Muttray also cited a study of 547 petroleum chemical workers. According to the abstract of this publication (article in Polish, [134]) the senses of smell and taste were examined. Hyposmia was found in $238(43.5 \%)$ and anosmia in 50 (9.2\%) subjects. Dysgeusia (distortion of the sense of taste) was identified in 319 (58.3\%) subjects, with no reaction at all in 102 (18.6\%) persons. In the control group (100 cotton industry workers) dysgeusia was determined in $69 \%$, anosmia in $24 \%$ of subjects. According to Muttray the exposure was described insufficiently.

\section{Animal experimental studies}

In an experiment conducted by the US National Toxicology Program (NTP), no conspicuous lesions of the olfactory epithelium were observed in rodents following inhalation of tetrahydrofurane [135]. In a further NTP study, degeneration of the olfactory epithelium was observed in all exposed mice following exposure to cyclohexanone in drinking water [136].

The capacity of 2-ethylhexanol to impair both the olfactory epithelium and the olfactory bulb in mice is demonstrated by Miyake et al. [137]: subchronic inhalation of 2-ethylhexanol induced degeneration of the olfactory epithelium at a lowest observed adverse effect level of $20 \mathrm{ppm}$. Following exposure for three months, changes in the olfactory bulb (such as a reduction in the glomeruli diameter, increase in the microglia) were also observed.

\section{Mechanism of olfactory dysfunction}

Odorants enter the nose orthonasally or retronasally and bind to receptors on the cilia of the olfactory sensory neurons in the olfactory epithelium. The stimulus is converted here into signals and forwarded to the brain. Whereas the respiratory epithelium lines the greater part of the respiratory tract, possesses no sensory neurons, and as the epithelium of the respiratory tract has the functions of keeping the tract clean and of moistening and warming the breathing air, the human olfactory epithelium is limited to a small area of approximately $2 \times 5$ square centimetres in the superior turbinate bone [138, 139]. Besides the approximately 10-30 million olfactory (bipolar) neurons, the olfactory epithelium consists of basal cells and supporting cells. The functions of the supporting cells (sustentacular cells) include biotransformation of xenobiotics [140].

Olfactory dysfunction can be caused by impairment of transport of the odorant molecules to the olfactory epithelium (conductive cause) and/or by sensorineural dysfunction.

Exclusively conductive or sensorineural dysfunction are rare; a combination of both is common. A possible conductive cause is for the transport of odours to the olfactory epithelium to be obstructed: in sufficient doses and with sufficiently long exposure, allergens and substances irritative and corrosive to the mucous membrane may cause rhinitis accompanied by inflammatory swelling of the mucous membrane. By obstructing nasal breathing, this can lead to anosmia, which is reversible once inflammation has subsided [141]. Conductive olfactory dysfunction may also be caused by chronic irritation by dusts such as calcium carbonate or cement [110].

Sensorineural causes can be broken down further according to the affected olfactory structure into damage to the olfactory epithelium, damage to the olfactory fibres, and central nervous effects.

The neurons of the olfactory epithelium are directly exposed to environmental influences. Their apical end is in direct contact with the external environment and not separated from it by synapses, and at their basal end they have direct access to the brain via 
their nerve fibre (axon): inhaled hazardous substances may therefore lead to impairment of the olfactory epithelium and, owing to the intracranial connection, consequently to damage to the bulbus olfactorius and higher brain regions [142].

Compared to all other neurons, those of the olfactory epithelium in the nose of vertebrates are unique in a further respect: they are able to self-renew after a certain lifespan (approximately 30-60 days in the case of rodents; data for human beings are not available [140]) by the differentiation of basal cells. The capacity for regeneration probably decreases with increasing age.

Of the industrial chemicals discussed in the present article, exposure to cadmium, nickel, zinc, cyclohexanone, styrene, acrylates and formaldehyde resulted in damage to the olfactory epithelium in animal experiments. Acute high exposure to reactive and soluble gas such as formaldehyde, chlorine and ammonia may directly damage the respiratory and sensory epithelium in the nose and induce lesions up to and including necroses, resulting in olfactory dysfunction [143]. In animal experiments, it was observed histologically that the olfactory epithelium appears "naked" following toxic exposure. It is described in these terms in one textbook of olfactory dysfunction and dysgeusia [142]. The textbook documents the histological finding of an olfactory biopsy of an anosmic patient following exposure to chlorine gas, by way of a photograph on which the loss of the olfactory receptor neurons is clearly visible.

The spectrum of histological changes that can occur following chronic exposure to irritants encompasses inflammation reactions, degeneration, atrophy, necrosis, keratinisation, hyperplasia, metaplasia and neoplasia [22]. Specific observations include both regeneration of the damaged epithelium by basal cells and metaplastic processes, besides a reduction in the number of olfactory cilia, degeneration of sensory and sustentacular cells and of the Bowman's glands and nerve fascicles, and necrosis of individual cells. The olfactory epithelium can therefore be replaced by respiratory/squamous epithelium.

Unspecific necrosis of cells of the olfactory epithelium can be caused by reactive irritative substances such as chlorine and sulfur dioxide, whereas cell-specific toxicity, affecting for example the sustentacular cells or sensory cells, can be induced by dibasic esters and methyl bromide. Methyl methacrylate is known to be metabolised by a non-specific esterase in the olfactory mucus to methanol and to methacrylic acid, which destroys the receptor cells [120]. The effect may be reversible when the basal cells, from which new receptor cells can form, remain intact.

In the olfactory epithelium itself, enzymes, particularly of the cytochrome P450 family (CYP), are expressed which metabolise toxic substances and can therefore both detoxify and toxify. The sustentacular cells express CYP proteins, which are responsible for the oxidation of xenobiotics. If these cells are damaged or destroyed, the metabolic activity of the CYP enzymes is also inhibited. Further factors, such as genetic polymorphisms, tobacco smoke and other exogenous substances (diallyl sulfide, m-xylene, 8-methoxypsoralen) may also have an inhibiting effect upon the respiratory CYP isoenzymes [22].

The activity of these enzymes decisively influences the toxic effects of many inhaled substances upon the respiratory and olfactory mucous membrane. Whereas, following inhalation, many toxic substances can be converted by metabolisation with the aid of these enzymes to intermediate products of lower toxicity, xenobiotic substances also exist that do not become toxic reactive intermediates until after metabolisation, as in the example of metabolic activation of carcinogenic nitrosamines from tobacco smoke catalysed by CYP2A13. CYP2A13 is strongly expressed in the nasal mucous membrane and is able to catalyse a range of atmospheric hazardous substances such as naphthalene, styrene and toluene [22].

The induction by cigarette smoke of CYP proteins (including CYP1A1) in the olfactory mucous membrane has been demonstrated in rats [144, 145]. Metabolisation to more toxic vs. less toxic products or intermediates may also potentially explain the apparently partly contradictory results regarding the impairment of olfactory function by inhaled substances in smokers. In an exposure study involving acrylates and methacrylates for example, the risk of developing olfactory dysfunction was greater in the non-smoker group [119]. Since tobacco smoke damages the sustentacular cells and thus inhibits enzymatic biotransformation, the creation of toxic intermediary products can also be prevented as a result, and the nasal function thus protected. Conversely, it is also conceivable that inhibition of the enzymes reduces detoxification of the substances, resulting in greater damage to the olfactory mucous membrane.

Altogether, little is known of central nervous effects leading to toxic olfactory dysfunction by substances. Following binding of the odorant molecules to the olfactory receptors, the stimulus information is further transmitted along the bundled axons of the olfactory receptor neurons (nervus olfactorius) through holes in the cribriform plate (lamina cribrosa) into the brain to specific glomeruli in the bulbus olfactorius. The glomeruli consist of the projections of the receptor neurons, which form synapses with the dendrites of pyramid-like mitral cells and of interneurons. Over 1000 axons of olfactory receptor neurons with the same receptor type project onto the dendrites of a single mitral cell [138]. Cadmium and manganese can be detected in the bulbus olfactorius of animals (see above, [38, 39, 63, 68, 72]) and in humans: Baader (1952) was able to determine atrophy of 
the nasal mucous membrane and an intensive yellow colouring of the olfactory bulb following the autopsy of an affected worker exposed to cadmium, which led him to suspect that cadmium reached the brain via the olfactory pathway [146]. After MRT research on non-human primates exposed to aerosolised manganese sulfate (particle diameter: 1.04-2.12 $\mu \mathrm{m}$ ) had already demonstrated transport of manganese via the olfactory pathway and accumulation of manganese in the olfactory bulb [147], increased deposition of manganese in the olfactory bulb was also detected on 7 welders by means of functional magnetic resonance tomography [63].

Over a decade ago, Oberdörster et al. voiced their suspicion that inhaled nanoparticles were able to penetrate the brain through the olfactory nerve [148]. It was shown recently that following inhalative exposure on mice, "quantum dots" (cadmium selenide and zinc sulfate nanocrystals) enter the brain and olfactory bulb by direct axonal transport from the nose; activation of microglia in the olfactory bulb was observed at the same time [149]. In humans, the progress of direct transfer of a substance - in this instance following application of thallium-201 $\left({ }^{201} \mathrm{TI}\right)$ - from the nose, via the olfactory epithelium and the olfactory nerve, into the brain was first demonstrated in 2010 by a Japanese team with the aid of SPECT computer tomography and magnetic resonance tomography [150]. Interestingly, this method was also used recently to document that significantly lower migration of ${ }^{201} \mathrm{TI}$ into the olfactory bulb occurred in patients with an olfactory dysfunction [151]. Neurodegeneration was also observed following exposure to manganese: intranasal exposure of mice to manganese chloride in saline solution led to increased necrosis of the granule cells in the bulbus olfactorius. Generally acting as inhibitory interneurons, the granule cells contribute to lateral inhibition and thus to contrast intensification of the activity patterns, sharper discrimination between different odours [138, 152].

At molecular level, a toxin-mediated reduction in the release of neurotransmitters could contribute to olfactory dysfunction: following intranasal application of a dilute cadmium chloride solution in mice, Czarnecki et al. demonstrated anosmia by means of a behavioural test, and a dose-dependent reduction in the odour-induced release by the olfactory nerve of neurotransmitters into the olfactory bulb [40]. Regarding the possible mechanism of action, Czarnecki et al. speculate that as a divalent cation, $\mathrm{Cd}^{2+}$ disrupts calcium-mediated neuronal signal transduction by blockage of the transmembrane calcium channels. Earlier studies had shown that release of neurotransmitters from the presynaptic terminals of the olfactory receptor neurons requires an influx of calcium ions via $\mathrm{N}$-type calcium channels. This permits the presumption that owing to the mechanism of amplifying signal transduction, even a minor cadmium-mediated reduction in the presynaptic calcium influx may have a major influence upon the entire release of transmitters by the olfactory nerve.

Diminished release of neurotransmitters following exposure to manganese was also demonstrated by Moberly et al. and Guilarte et al. in the olfactory bulb and in the basal ganglia [153, 154]. Whereas no histopathological changes were evident, the study by Moberly et al. showed that intranasal instillation of as little as $2 \mu \mathrm{g} \mathrm{MnCl}_{2}$ in mice was sufficient to cause significant changes in odour-induced neurotransmitter release from the olfactory nerve [153]. At $200 \mu \mathrm{g}$, the reduction was $90 \%$. This effect may be presumed attributable to a central nervous effect of the manganese, since the release of neurotransmitters was reduced not only after odour stimulation, but also after electrical stimulation.

\section{Evaluation}

As yet, few reasonably reliable epidemiological studies have been produced of the olfactotoxic effect of industrial chemicals. Interpretation of these publications revealed that cadmium, nickel, chromium and formaldehyde encountered under workplace conditions can be assumed with reasonable certainty to impair the human olfactory function. This finding is supported for the most part by the results of animal experiments.

The level of evidence for an empirically demonstrated relationship between the development of olfactory dysfunction and exposure to potentially olfactotoxic substances at workplaces can be considered comparatively weak in the majority of cases for the following reasons:

The majority of epidemiological studies of this specific occupational problem are cross-sectional involving heterogeneous collectives in which the individual levels and durations of exposure often differ widely. Despite high variance in olfactory function within the wider population, the studies discussed in this article consider comparatively small groups of people. Aside from the large-scale poliomyelitis prevention campaign employing zinc sulfate nasal spray, only Pyatayev [73] and Casjens et al. [67] have studied several hundred individuals. According to Mücke and Lemmen [126], olfactory sensitivity in a population approximately follows a normal distribution: "(...) although the breadth of perceived concentrations may differ by a factor of up to a hundred within the group (...)". To our knowledge, no valid specific prospective cohort studies of work-related olfactory dysfunction other than Casjens et al. are available. However cross sectional analysis of data collected in large nationwide surveys such as the US National Health and Nutrition Examination Survey (NHANES) provides estimates representative at national level of the prevalence of taste and smell impairment in the US population and 
also identifies exposure variables correlating with olfactory dysfunction [155-158]. In the German National Cohort (GNC), a random sample of the general population will be taken by 18 German regional study centres, including a total of 100,000 women and 100,000 men aged 20-69 years, with the aim of increasing understanding of the role of particular risk factors in the development of major forms of chronic disease. Special emphasis will be placed on selected lifestyle factors, but also on occupational and environmental influences. One functional measurement that will be performed is of olfactory function [159].

Details of the reversibility or persistence of olfactory dysfunction induced by working substances are often unavailable. More follow-up studies of workers who have changed jobs could be useful. Olfactory dysfunction is not easily quantified. Standardised olfactory tests were not developed until recent decades. Comparison between the study results is rendered more difficult by differences between the test methods employed. Olfactory self-assessment tends to be unreliable and it has been shown that people do not perform well when compared with psychophysical testing [6].

Monitoring of all relevant confounders is difficult in workplace assessments. Olfactory function is known to decrease with increasing age. Indications exist of differences between the sexes, and differences in ethnic background may also be associated with differences in olfactory function. Olfactory function may be affected by alcoholism and smoking behaviour, medication, hormonal impacts, hunger and environmental influences [160162].

The problem of mixed exposure exists at many workplaces, as described for example in Chapter 2 with regard to the metals industry. Firefighters, paramedics and police officers may be exposed to a range of different dusts and fumes in disaster situations. An impressive example is provided by Altman et al. and Dalton [24, 163]: following the terror attack on the World Trade Center in New York in 2001, many responders and local residents exhibited impairment of olfactory function, in addition to the symptoms of other conditions. Workers are also exposed in day-to-day operations in sewage works and landfills to a range of irritants and agents corrosive to the mucous membrane which may lead to impairment of the sense of smell [164].

Comparison of the concentrations in the studies cited with the current situation at workplaces in central Europe is hampered by the gaps in the information provided by the studies on the sampling and analysis methods. Convincing evidence that the olfactory dysfunction triggered by olfactotoxic industrial chemicals is the critical, namely most sensitive toxicological effect of these substances, has not yet been provided.
In general, relevant physiological differences, and also anatomical differences, must be considered when the results of animal experiments are transferred to humans. Whereas humans are oronasal breathers, rodents are obligate nasal breathers. In humans, the olfactory epithelium covers approximately $3 \%$ of the nasal cavity; in rats for example, it covers as much as $50 \%$. The situation is similar for mice, rabbits and dogs. Owing to the olfactory epithelium's sheltered location in human beings, less than 15\% of the air inhaled through the nose reaches it - substantially less than for example in rodents [22].

Certain differences are observed in the activity of metabolic enzymes in laboratory animals and humans. High concentrations of the two cytochrome P450 isoforms which are required for the conversion of styrene to styrene oxide were for example detected in respiratory fractions of rats and mice, but not in those of humans [165]. At styrene exposure concentrations resembling those of occupational exposure, mice and rats exhibit extensive damage, whilst humans exhibit no indication of a dose-dependent long-term change in olfactory function $[124,125,127,128]$.

\section{Conclusion and future prospects}

An impaired olfactory function not only diminishes the quality of life of those affected, but can also present a workplace hazard for the workers and the company if it results in hazardous substances no longer being detected sufficiently quickly.

Isolated indications that chronic occupational exposure to comparatively low levels of the substances stated above has a harmful impact upon olfactory function should be examined more closely, as should the issue of the effects' reversibility. In this context, the significance of neuroplasticity must be considered, which seeks to compensate for failures in the sensory apparatus.

Since many affected individuals are shown not to be aware of their olfactory dysfunction, greater consideration should be given to regular check-ups of the olfactory function of workers at certain workplaces. At present, olfactory check-ups are performed only in very few working areas. In Germany, tasks associated with room fumigation and room disinfection are an example $[3,166]$. SUVA, the Swiss accident insurance institution, recommends olfactory tests as part of occupational health monitoring for persons working with smellable toxic and explosive hazardous substances [167]. The substances occurring at the workplace concerned should be included in the olfactory test, in order for selective anosmia for certain industrial chemicals also to be detected [126]. Normal accustomisation effects such as adaptation and habituation that may impair the sensing of possible hazardous substances at the workplace should be considered at the same time. 
An olfactory test not only ensures that the employees with potential contact with smellable hazardous substances are able to sense them and their warning function, but could also serve as a means of early detection of pathological changes. Rose et al. and Mascagni et al. for example discuss the possible use of olfactory dysfunction as an early indicator of toxic effects induced by cadmium [34, 37]. It is also possible that other neurotoxic substances not only cause direct damage to the olfactory epithelium, but also damage the central nervous system following transport through the nose into the brain. Accordingly, olfactory dysfunction could have an early-warning function for potential damage to the brain induced by the same neurotoxins. Olfactory dysfunction also serves as a marker for certain neurodegenerative diseases. In conjunction with the idiopathy of Parkinson's syndrome, olfactory dysfunction may arise as early as four to six years before the first motor dysfunction typical of Parkinson's, such as shaking and muscular rigidity $[16,168]$.

Not only must employees with severe olfactory dysfunction be advised that they are able to detect smellable hazardous substances only poorly, if at all, suitable measures must also be taken at work and in private life to prevent a hazard arising.

\section{Acknowledgements}

We wish to thank Professor Thomas Hummel, head of the Interdisciplinary Center Smell \& Taste (University Hospital Carl Gustav Carus, Dresden), for his critical review of the first version of the manuscript.

\section{Authors' contributions \\ S.W. produced the first draft which was revised by E.N. Evaluation and conclusion were jointly written by both authors. Both authors read and approved the final manuscript.}

\section{Ethics approval and consent to participate}

Not applicable.

\section{Consent for publication}

Not applicable.

\section{Competing interests}

The authors declare that they have no competing interests.

\section{Publisher's Note}

Springer Nature remains neutral with regard to jurisdictional claims in published maps and institutional affiliations.

Received: 14 February 2018 Accepted: 30 July 2018

Published online: 04 September 2018

\section{References}

1. Doty RL. A review of olfactory dysfunctions in man. Am J Otolaryngol. 1979; 1(1):57-79.

2. Muttray A, Konietzko J. Störungen des Riechvermögens durch und für Arbeitsstoffe. Arbeitsmed Sozialmed Umweltmed. 1994;29:409-13.

3. BMAS (Federal Ministry of Labour and Social Affairs). Neufassung der Empfehlung des BMA zur Durchführung der Eignungsuntersuchung von Befähigungsscheinbewerbern für Begasungen gemäß Anhang V Nr. 5.2 Abs. 2 Ziffer 2 GefStoffV. BArbBI. 1995;12:41-4. berichtigt in BArbBI. 1996. 4:46.

4. Doty RL. Neurotoxic exposure and impairment of the chemical senses of taste and smell. Handb Clin Neurol. 2015;131:299-324.
5. AWMF - The Association of the Scientific Medical Societies (Arbeitsgemeinschaft der Wissenschaftlichen Medizinischen Fachgesellschaften e.V.): S2k-Leitlinie 017/050: Riech- und Schmeckstörungen; 2016. https://www.awmf.org/uploads/tx_szleitlinien/ 017-050I_S2k_Riech-und-Schmeckst\%c3\%b6rungen_2017-03.pdf. Accessed 25 Jan 2018.

6. Hummel T, Whitcroft KL, Andrews P, Altundag A, Cinghi C, Costanzo RM, et al. Position paper on olfactory dysfunction. Rhinol Suppl. 2017;54(26):1-30.

7. Doty RL, Shaman P, Dann M. Development of the University of Pennsylvania Smell Identification Test: a standardized microencapsulated test of olfactory function. Physiol Behav. 1984;32(3):489-502.

8. Kobal G, Hummel T, Sekinger B, Barz S, Roscher S, Wolf S. "Sniffin' sticks": screening of olfactory performance. Rhinology. 1996;34(4):222-6.

9. Hummel T, Sekinger B, Wolf SR, Pauli E, Kobal G. Sniffin' sticks': olfactory performance assessed by the combined testing of odor identification, odor discrimination and olfactory threshold. Chem Senses. 1997;22(1):39-52.

10. Hummel T, Welge-Lüssen A. Erfassung des Riech-und Schmeckvermögens, In: Hummel T, Welge-Lüssen A, editors. Riech-und Schmeckstörungen. Stuttgart: Thieme; 2009; p. 43-59.

11. Stuck B, Beule A, Damm M, Gudziol H, Hüttenbrink KB, Landis B, et al. Positionspapier "Die chemosensorische Testung bei der gutachterlichen Abklärung von Riechstörungen". Laryngo-Rhino-Otologie. 2014;93(05):327-9.

12. Hummel T, Kobal G, Gudziol H, Mackay-Sim A. Normative data for the "Sniffin' sticks" including tests of odor identification, odor discrimination, and olfactory thresholds: an upgrade based on a group of more than 3,000 subjects. Eur Arch Otorhinolaryngol. 2007;264(3):237-43.

13. University Hospital Carl Gustav Carus: Normative data for Sniffin Sticks 2012:; https://www.uniklinikum-dresden.de/de/das-klinikum/kliniken-poliklinikeninstitute/hno/forschung/interdisziplinaeres-zentrum-fuer-riechen-undschmecken/downloads/downloads/SDI_Normwerte_2012.pdf (2016). Accessed 25 Jan 2018.

14. Kuner T, Schaefer AT. Moleküle, Zellen und Netzwerke für die Verarbeitung von Geruchsreizen im Riechkolben der Maus. e-Neuroforum. 2011;17(3):102-9.

15. Zou J, Wang W, Pan YW, Lu S, Xia Z. Methods to measure olfactory behavior in mice. Curr Protoc Toxicol. 2015;63:11 8 1-21.

16. Hüttenbrink KB, Hummel T, Berg D, Gasser T, Hähner A. Riechstörungen: Häufig im Alter und wichtiges Frühsymptom neurodegenerativer Erkrankungen. Dtsch Arztebl Int. 2013;110:1-7.

17. Croy I, Olgun S, Mueller L, Schmidt A, Muench M, Hummel C, et al. Peripheral adaptive filtering in human olfaction? Three studies on prevalence and effects of olfactory training in specific anosmia in more than 1600 participants. Cortex. 2015;73:180-7.

18. Mott AE, Leopold DA. Disorders in taste and smell. Med Clin North Am. 1991;75(6):1321-53.

19. Damm M, Temmel A, Welge-Lüssen A, Eckel H, Kreft MP, Klussmann J, et al. Riechstörungen HNO. 2004;52(2):112-20.

20. Fonteyn S, Huart C, Deggouj N, Collet S, Eloy P, Rombaux P. Non-sinonasalrelated olfactory dysfunction: a cohort of 496 patients. Eur Ann Otorhinolaryngol Head Neck Dis. 2014;131(2):87-91.

21. Gobba F. Olfactory toxicity: long-term effects of occupational exposures. Int Arch Occup Environ Health. 2006;79(4):322-31.

22. Dalton P. Olfactory toxicity in humans and experimental animals. In: Morris JBSD, editor. Toxicology of the nose and upper airways. New York: Informa Healthcare; 2010. p. 215-41.

23. Herberhold C. Funktionsprüfungen und Störungen des Geruchssinnes. Arch Otorhinolaryngol. 1975;210(1):67-164.

24. Dalton PH, Opiekun RE, Gould M, McDermott R, Wilson T, Maute C, et al Chemosensory loss: functional consequences of the world trade center disaster. Environ Health Perspect. 2010;118(9):1251-6.

25. Klimek L, Muttray A, Moll B, Konietzko J, Mann W. Riechstörungen durch inhalative Schadstoffexposition. Laryngo-Rhino-Otologie. 1999;78(11):620-6.

26. Muttray A, Haxel B, Mann W, Letzel S. Anosmie und Rhinitis durch eine berufliche Lösungsmittelexposition. HNO. 2006;54(11):883-7.

27. Amoore J. Effects of chemical exposure on olfaction in humans. In: Barrow CS, editor. Toxicology of the nasal passages. New York: Hemisphere Publishing Corp; 1986. p. 155-90.

28. Sunderman FW Jr. Nasal toxicity, carcinogenicity, and olfactory uptake of metals. Ann Clin Lab Sci. 2001;31(1):3-24.

29. Friberg L. Health hazards in the manufacture of alkaline accumulators with special reference to chronic cadmium poisoning; a clinical and experimental study. Acta Med Scand Suppl. 1950;240:1-124. 
30. Baader EW. Die chronische Kadmiumvergiftung. Dtsch Med Wochenschr. 1951;76(14):484-7.

31. Potts CL. Cadmium proteinuria - the health of battery workers exposed to cadmium oxide dust. Ann Occup Hyg. 1965;8:55-61.

32. Liu YZ, Huang JX, Luo CM, Xu BH, Zhang CJ. Effects of cadmium on cadmium smelter workers. Scand J Work Environ Health. 1985;11(Suppl 4):29-32.

33. Adams RG, Crabtree N. Anosmia in alkaline battery workers. Br J Ind Med. 1961;18:216-21.

34. Rose CS, Heywood PG, Costanzo RM. Olfactory impairment after chronic occupational cadmium exposure. J Occup Med. 1992;34(6):600-5.

35. Rydzewski B, Sulkowski W, Miarzynska M. Olfactory disorders induced by cadmium exposure: a clinical study. Int J Occup Med Environ Health. 1998; 11(3):235-45.

36. Sulkowski WJ, Rydzewski B, Miarzynska M. Smell impairment in workers occupationally exposed to cadmium. Acta Otolaryngol. 2000;120(2):316-8.

37. Mascagni P, Consonni D, Bregante G, Chiappino G, Toffoletto F. Olfactory function in workers exposed to moderate airborne cadmium levels. Neurotoxicology. 2003;24(4-5):717-24.

38. Sun TJ, Miller ML, Hastings L. Effects of inhalation of cadmium on the rat olfactory system: behavior and morphology. Neurotoxicol Teratol. 1996; 18(1):89-98.

39. Bondier JR, Michel G, Propper A, Badot PM. Harmful effects of cadmium on olfactory system in mice. Inhal Toxicol. 2008:20(13):1169-77.

40. Czarnecki LA, Moberly AH, Rubinstein T, Turkel DJ, Pottackal J, McGann JP. In vivo visualization of olfactory pathophysiology induced by intranasal cadmium instillation in mice. Neurotoxicology. 2011;32(4):441-9.

41. Czarnecki LA, Moberly AH, Turkel DJ, Rubinstein T, Pottackal J, Rosenthal MC, et al. Functional rehabilitation of cadmium-induced neurotoxicity despite persistent peripheral pathophysiology in the olfactory system. Toxicol Sci. 2012;126(2):534-44.

42. Williams CR, Gallagher EP. Effects of cadmium on olfactory mediated behaviors and molecular biomarkers in coho salmon (Oncorhynchus kisutch). Aquat Toxicol. 2013;140-141:295-302.

43. National Toxicology Program. NTP toxicology and carcinogenesis studies of nickel subsulfide (CAS No. 12035-72-2) in F344 rats and B6C3F1 mice (Inhalation Studies). Natl Toxicol Program Tech Rep Ser. 1996:453:1-365.

44. National Toxicology Program. NTP toxicology and carcinogenesis studies of nickel sulfate hexahydrate (CAS No. 10101-97-0) in F344 rats and B6C3F1 mice (Inhalation Studies). Natl Toxicol Program Tech Rep Ser. 1996;454:1380.

45. Evans JE, Miller ML, Andringa A, Hastings L. Behavioral, histological, and neurochemical effects of nickel (II) on the rat olfactory system. Toxicol Appl Pharmacol. 1995;130(2):209-20

46. Miller ML, Andringa A, Evans JE, Hastings L. Microvillar cells of the olfactory epithelium: morphology and regeneration following exposure to toxic compounds. Brain Res. 1995;669(1):1-9.

47. Lewis J, Hahn F, Dahl A. Transport of inhaled toxicants to the centra nervous system. Characteristics of a nose-brain barrier. The vulnerable brain and environmental risks. 1994:3:77-103.

48. Henriksson J, Tallkvist J, Tjälve H. Uptake of nickel into the brain via olfactory neurons in rats. Toxicol Lett. 1997:91(2):153-62.

49. Tallkvist J, Henriksson J, d'Argy R, Tjalve H. Transport and subcellular distribution of nickel in the olfactory system of pikes and rats. Toxicol Sci. 1998;43(2):196-203.

50. Jia C, Roman C, Hegg CC. Nickel sulfate induces location-dependent atrophy of mouse olfactory epithelium: protective and proliferative role of purinergic receptor activation. Toxicol Sci. 2010;115(2):547-56.

51. Zhao J, Bowman L, Zhang X, Shi X, Jiang B, Castranova V, et al. Metallic nickel nano- and fine particles induce JB6 cell apoptosis through a caspase8/AIF mediated cytochrome c-independent pathway. J Nanobiotechnology. 2009;7:2.

52. Gautam SH, Otsuguro Kl, Ito S, Saito T, Habara Y. T-type Ca2+ channels mediate propagation of odor-induced $\mathrm{Ca} 2+$ transients in rat olfactory receptor neurons. Neuroscience. 2007;144(2):702-13.

53. Seeber H, Fikentscher R, Roseburg B. Geruchs- und Geschmacksstörungen bei Chromfarbenarbeitern. Z Gesamte Hyg. 1976;22(11):820-2.

54. Seeber H, Fikentscher R. Schäden der Nasenschleimhaut und Riechstörungen durch berufliche Chromstaubexposition. Z Gesamte Hyg. 1980;26(7):506-8

55. Watanabe S, Fukuchi Y. Occupational impairment of the olfactory sense of chromate producing workers (in Japanese). Sangyo Igaku. 1981;23(6):606-11.
56. Kitamura F, Yokoyama K, Araki S, Nishikitani M, Choi JW, Yum YT, et al. Increase of olfactory threshold in plating factory workers exposed to chromium in Korea. Ind Health. 2003;41(3):279-85.

57. Aiver RG, Kumar G. Nasal manifestations in chromium industry workers. Indian J Otolaryngol Head Neck Surg. 2003;55(2):71-3.

58. Lucchini R, Bergamaschi E, Smargiassi A, Festa D, Apostoli P. Motor function, olfactory threshold, and hematological indices in manganese-exposed ferroalloy workers. Environ Res. 1997;73(1-2):175-80.

59. Mergler D, Huel G, Bowler R, Iregren A, Belanger S, Baldwin M, et al. Nervous system dysfunction among workers with long-term exposure to manganese. Environ Res. 1994;64(2):151-80.

60. Antunes MB, Bowler R, Doty RL. San Francisco/Oakland Bay bridge welder study: olfactory function. Neurology. 2007;69(12):1278-84

61. Bowler RM, Roels HA, Nakagawa S, Drezgic M, Diamond E, Park R, et al. Dose-effect relationships between manganese exposure and neurological, neuropsychological and pulmonary function in confined space bridge welders. Occup Environ Med. 2007;64(3):167-77.

62. Bowler RM, Gocheva V, Harris M, Ngo L, Abdelouahab N, Wilkinson J, et al. Prospective study on neurotoxic effects in manganese-exposed bridge construction welders. Neurotoxicology. 2011;32(5):596-605.

63. Sen S, Flynn MR, Du G, Troster Al, An H, Huang X. Manganese accumulation in the olfactory bulbs and other brain regions of "asymptomatic" welders. Toxicol Sci. 2011;121(1):160-7.

64. Guarneros M, Ortiz-Romo N, Alcaraz-Zubeldia M, Drucker-Colín R, Hudson R. Nonoccupational environmental exposure to manganese is linked to deficits in peripheral and central olfactory function. Chemical senses. 2013;38(9):783-91.

65. Lucchini RG, Guazzetti S, Zoni S, Donna F, Peter S, Zacco A, et al. Tremor, olfactory and motor changes in Italian adolescents exposed to historical ferro-manganese emission. Neurotoxicology. 2012;33(4):687-96.

66. Iannilli E, Gasparotti R, Hummel T, Zoni S, Benedetti C, Fedrighi C, et al. Effects of manganese exposure on olfactory functions in teenagers: a pilot study. PLoS One. 2016;11(1):e0144783.

67. Casjens S, Pesch B, Robens S, Kendzia B, Behrens T, Weiss T, et al. Associations between former exposure to manganese and olfaction in an elderly population: results from the Heinz Nixdorf recall study. Neurotoxicology. 2017;58:58-65.

68. Tjalve $\mathrm{H}$, Henriksson J. Uptake of metals in the brain via olfactory pathways. Neurotoxicology. 1999;20(2-3):181-95.

69. Tjalve H, Henriksson J, Tallkvist J, Larsson BS, Lindquist NG. Uptake of manganese and cadmium from the nasal mucosa into the central nervous system via olfactory pathways in rats. Pharmacol Toxicol. 1996;79(6):347-56.

70. Tjalve $H$, Mejare $\mathrm{C}$, Borg-Neczak K. Uptake and transport of manganese in primary and secondary olfactory neurones in pike. Pharmacol Toxicol. 1995; 77(1):23-31.

71. Foster ML, Rao DB, Francher T, Traver S, Dorman DC. Olfactory toxicity in rats following manganese chloride nasal instillation: a pilot study. Neurotoxicology. 2018;64:284-90.

72. Thompson K, Molina RM, Donaghey T, Savaliya S, Schwob JE, Brain JD. Manganese uptake and distribution in the brain after methyl bromideinduced lesions in the olfactory epithelia. Toxicol Sci. 2011;120(1):163-72.

73. Pyatayev GE. The state of olfactory function in zinc production workers, in Russian. Zh Ushn Nos Gorl Bolezn. 1971;31:17-21.

74. Anonymous. Zinc Sulphate spray for prevention of poliomyelitis. Br Med J. 1938;1 (4034):953-4.

75. Tisdall F, Brown A, Defries R. Persistent anosmia following zinc sulfate nasal spraying. J Pediatr. 1938;13(1):60-2.

76. Davidson TM, Smith WM. The Bradford Hill criteria and zinc-induced anosmia: a causality analysis. Arch Otolanyngol Head Neck Surg. 2010;136(7):673-6.

77. Alexander TH, Davidson TM. Intranasal zinc and anosmia: the zinc-induced anosmia syndrome. Laryngoscope. 2006;116(2):217-20.

78. Jafek BW, Linschoten MR, Murrow BW. Anosmia after intranasal zinc gluconate use. Am J Rhinol. 2004;18(3):137-41.

79. Osmond-McLeod MJ, Osmond RI, Oytam Y, McCall MJ, Feltis B, Mackay-Sim A, et al. Surface coatings of $\mathrm{ZnO}$ nanoparticles mitigate differentially a host of transcriptional, protein and signalling responses in primary human olfactory cells. Part Fibre Toxicol. 2013;10(1):54.

80. Lim JH, Davis GE, Wang Z, Li V, Wu Y, Rue TC, et al. Zicam-induced damage to mouse and human nasal tissue. PLoS One. 2009;4(10):e7647.

81. McBride K, Slotnick B, Margolis FL. Does intranasal application of zinc sulfate produce anosmia in the mouse? An olfactometric and anatomical study. Chem Senses. 2003;28(8):659-70. 
82. Burd GD. Morphological study of the effects of intranasal zinc sulfate irrigation on the mouse olfactory epithelium and olfactory bulb. Microsc Res Tech. 1993;24(3):195-213.

83. Cancalon P. Degeneration and regeneration of olfactory cells induced by $\mathrm{ZnSO}_{4}$ and other chemicals. Tissue Cell. 1982;14(4):717-33.

84. Harding JW, Getchell TV, Margolis FL. Denervation of the primary olfactory pathway in mice. V. Long-term effect of intranasal $\mathrm{ZnSO}_{4}$ irrigation on behavior, biochemistry and morphology. Brain Res. 1978;140(2):271-85.

85. Matulionis DH. Light and electron microscopic study of the degeneration and early regeneration of olfactory epithelium in the mouse. Am J Anat 1976;145(1):79-99.

86. Smith CG. Changes in the olfactory mucosa and the olfactory nerves following intranasal treatment with one per cent zinc sulphate. Can Med Assoc J. 1938;39(2):138-40.

87. Benvenuti S, Gagliardo A. Homing behaviour of pigeons subjected to unilateral zinc sulphate treatment of their olfactory mucosa. J Exp Biol. 1996; 199(11):2531-5.

88. Hansen LF, Hammer M, Petersen SH, Nielsen GD. Effects of intranasal $\mathrm{ZnSO}_{4}$ irrigation on olfactory and trigeminal cues. Physiol Behav. 1994;55(4):699-704.

89. Mayer AD, Rosenblatt JS. Peripheral olfactory deafferentation of the primary olfactory system in rats using $\mathrm{ZnSO}_{4}$ nasal spray with special reference to maternal behavior. Physiology Behav. 1993;53(3):587-92.

90. Winans SS, Powers JB. Olfactory and vomeronasal deafferentation of male hamsters: histological and behavioral analyses. Brain Res. 1977;126(2):325-44.

91. Alberts JR, Galef BG Jr. Acute anosmia in the rat: a behavioral test of a peripherally-induced olfactory deficit. Physiol Behav. 1971;6(5):619-21.

92. Duncan-Lewis CA, Lukman RL, Banks RK. Effects of zinc gluconate and 2 other divalent cationic compounds on olfactory function in mice. Comp Med. 2011;61(4):361-5.

93. Viswaprakash N, Dennis JC, Globa L, Pustovyy O, Josephson EM, Kanju P, et al. Enhancement of odorant-induced responses in olfactory receptor neurons by zinc nanoparticles. Chem Senses. 2009:34(7):547-57.

94. Gao L, Yang ST, Li S, Meng Y, Wang H, Lei H. Acute toxicity of zinc oxide nanoparticles to the rat olfactory system after intranasal instillation. J Appl Toxicol. 2013;33(10):1079-88.

95. Sorokowska A, Schriever VA, Gudziol V, Hummel C, Hähner A, lannilli E, et al. Changes of olfactory abilities in relation to age: odor identification in more than 1400 people aged 4 to 80 years. Europ Arch Otorhinolaryngol. 2015; 272(8):1937-44.

96. Muttray A, Moll B, Letzel S. Die sozialmedizinische Bedeutung von Riechstörungen am Beispiel einer Kasuistik. Arbeitsmed Sozialmed Umweltmed. 2003;38:428-34.

97. Mossad SB. Effect of zincum gluconicum nasal gel on the duration and symptom severity of the common cold in otherwise healthy adults. QJM. 2003;96(1):35-43.

98. FDA: Warnings on Three Zicam Intranasal Zinc Products. https://wayback. archive-it.org/7993/20170113083935/http://www.fda.gov/ForConsumers/ ConsumerUpdates/ucm 166931.htm. Accessed 25 Jan 2018.

99. Hamidovic A. Position on zinc delivery to olfactory nerves in intranasal insulin phase I-III clinical trials. Contemp Clin Trials. 2015;45(Pt B):277-80.

100. Brunner YF, Benedict C, Freiherr J. Intranasal insulin reduces olfactory sensitivity in normosmic humans. J Clin Endocrinol Metab. 2013;98(10):E1626-30.

101. Herranz Gonzalez-Botas J, Padin SA. Nasal gel and olfactory cleft. Acta Otorrinolaringol Esp. 2012;63(5):370-5.

102. Calvert GM, Mueller CA, Fajen JM, Chrislip DW, Russo J, Briggle T, et al. Health effects associated with sulfuryl fluoride and methyl bromide exposure among structural fumigation workers. Am J Public Health. 1998;88(12):1774-80.

103. DFG (Deutsche Forschungsgemeinschaft). Chlorpikrin [MAK Value Documentation in German language, 1974]. In: DFG, editor. The MAKCollection for Occupational Health and Safety. Weinheim: Wiley-VCH Verlag GmbH \& Co. KGaA; 1974.

104. Quandt SA, Walker FO, Talton JW, Summers P, Chen H, McLeod DK, et al. Olfactory function in Latino farmworkers: subclinical neurological effects of pesticide exposure in a vulnerable population. J Occup Environ Med. 2016; 58(3):248-53.

105. Shrestha S, Kamel F, Umbach DM, Beane Freeman LE, Koutros S, Alavanja M, et al. Nonmotor symptoms and Parkinson disease in United States farmers and spouses. PLoS One. 2017;12(9):e0185510.

106. Schwob JE, Youngentob SL, Mezza RC. Reconstitution of the rat olfactory epithelium after methyl bromide-induced lesion. J Comp Neurol. 1995; 359(1):15-37.
107. Eisenbrandt DL, Nitschke KD. Inhalation toxicity of sulfuryl fluoride in rats and rabbits. Fundam Appl Toxicol. 1989;12(3):540-57.

108. Mattsson JL, Albee RR, Eisenbrandt DL, Chang LW. Subchronic neurotoxicity in rats of the structural fumigant, sulfuryl fluoride. Neurotoxicol Teratol. 1988;10(2):127-33.

109. Spealman CR. Odors, odorants, and deodorants in aviation. Ann N Y Acad Sci. 1954;58(2):40-3.

110. Lenhardt E, Rollin H. Berufsbedingte Riechstörungen. HNO. 1969;17:104-6.

111. Holmström M, Wilhelmsson B. Respiratory symptoms and pathophysiological effects of occupational exposure to formaldehyde and wood dust. Scand J Work Environ Health. 1988;14(5):306-11.

112. Hisamitsu M, Okamoto Y, Chazono H, Yonekura S, Sakurai D, Horiguchi S, et al. The influence of environmental exposure to formaldehyde in nasal mucosa of medical students during cadaver dissection. Allergol Int. 2011; 60(3):373-9.

113. Kilburn KH, Seidman BC, Warshaw R. Neurobehavioral and respiratory symptoms of formaldehyde and xylene exposure in histology technicians. Arch Environ Health. 1985;40(4):229-33.

114. Edling $\mathrm{C}$, Hellquist $\mathrm{H}$, Odkvist L. Occupational exposure to formaldehyde and histopathological changes in the nasal mucosa. Br J Ind Med. 1988; 45(11):761-5.

115. Arts JH, Rennen MA, de Heer C. Inhaled formaldehyde: evaluation of sensory irritation in relation to carcinogenicity. Regul Toxicol Pharmacol. 2006:44(2):144-60

116. Cassee FR, Groten JP, Feron VJ. Changes in the nasal epithelium of rats exposed by inhalation to mixtures of formaldehyde, acetaldehyde, and acrolein. Fundam Appl Toxicol. 1996;29(2):208-18.

117. Li Y, Chen H, Yin Y, Han F, Ye X, Ling S. Formaldehyde inhalation may damage olfactory bulb and hippocampus in rats. Zhejiang da xue xue bao Yi xue ban Journal of Zhejiang University Medical Sciences. 2010;39(3):272-7.

118. Zhang Q, Yan W, Bai Y, Zhu Y, Ma J. Repeated formaldehyde inhalation impaired olfactory function and changed SNAP25 proteins in olfactory bulb. Int J Occup Environ Health. 2014;20(4):308-12

119. Schwartz BS, Doty RL, Monroe C, Frye R, Barker S. Olfactory function in chemical workers exposed to acrylate and methacrylate vapors. Am J Public Health. 1989:79(5):613-8.

120. Muttray A, Schmitt B, Klimek L. Effects of methyl methacrylate on the sense of smell. Cent Eur J Occup Environ Med. 1997:3:58-66.

121. Muttray A, Gosepath J, Brieger J, Faldum A, Zagar C, Mayer-Popken O, et al. V17 Zur Wirkung von 50 ppm Methylmethacrylat auf die oberen Atemwege gesunder Probanden. Arbeitsmed Sozialmed Umweltmed. 2007:42(3):105.

122. DFG (Deutsche Forschungsgemeinschaft). Methyl methacrylate [MAK Value Documentations, Vol. 26, 2010]. In: DFG, editor. The MAK-Collection for Occupational Health and Safety. Weinheim: Wiley-VCH Verlag GmbH \& Co. KGaA; 2010.

123. Cheng SF, Chen ML, Hung PC, Chen CJ, Mao IF. Olfactory loss in poly(acrylonitrile-butadiene-styrene) plastic injection-moulding workers. Occup Med (Lond). 2004;54(7):469-74

124. Dalton P, Cowart B, Dilks D, Gould M, Lees PS, Stefaniak A, et al. Olfactory function in workers exposed to styrene in the reinforced-plastics industry. Am J Ind Med. 2003:44(1):1-11.

125. Dalton P, Lees PS, Gould M, Dilks D, Stefaniak A, Bader M, et al. Evaluation of long-term occupational exposure to styrene vapor on olfactory function. Chem Senses. 2007;32(8):739-47.

126. Mücke W, Lemmen C. Duft und Geruch: Wirkungen und gesundheitliche Bedeutung von Geruchsstoffen. Heidelberg, München, Landsberg, Frechen, Hamburg: ecomed-Storck GmbH; 2010.

127. Cruzan G, Cushman JR, Andrews LS, Granville GC, Miller RR, Hardy CJ, et al. Subchronic inhalation studies of styrene in CD rats and CD-1 mice. Fundam Appl Toxicol. 1997;35(2):152-65.

128. Cruzan G, Cushman JR, Andrews LS, Granville GC, Johnson KA, Hardy CJ, et al. Chronic toxicity/oncogenicity study of styrene in $C D$ rats by inhalation exposure for 104 weeks. Toxicol Sci. 1998;46(2):266-81.

129. Green T, Lee R, Toghill A, Meadowcroft S, Lund V, Foster J. The toxicity of styrene to the nasal epithelium of mice and rats: studies on the mode of action and relevance to humans. Chem Biol Interact. 2001;137(2):185-202.

130. Schwartz BS, Ford DP, Bolla Kl, Agnew J, Rothman N, Bleecker ML. Solventassociated decrements in olfactory function in paint manufacturing workers. Am J Ind Med. 1990;18(6):697-706.

131. Sandmark B, Broms I, Lofgren L, Ohlson CG. Olfactory function in painters exposed to organic solvents. Scand J Work Environ Health. 1989;15(1):60-3. 
132. Ahlstrom R, Berglund B, Berglund U, Lindvall T, Wennberg A. Impaired odor perception in tank cleaners. Scand J Work Environ Health. 1986;12(6):574-81.

133. Muttray A, Klimek L, Jung D, Rose D, Mann W, Konietzko J. Die toxische Hyp- und Anosmie - eine "vergessene" Berufskrankheit. Zentralbl Arbeitsmed. 1998:48:66-71.

134. Latkowski B, Zalewski P, Najwer K, Zbrzezny K, Czyzewski I. Evaluation of the senses of taste and smell in petroleum chemistry workers based on 3-year observations, in Polish. Med Pr. 1981;32(1):51-7.

135. National Toxicology Program. NTP toxicology and carcinogenesis studies of tetrahydrofuran (CAS No. 109-99-9) in F344/N rats and B6C3F1 mice (Inhalation Studies). Natl Toxicol Program Tech Rep Ser. 1998;475:1-244.

136. National Toxicology Program. NTP toxicity studies of cyclohexanone oxime administered by drinking water to B6C3F1 mice (CAS No. 100-64-1). NTP toxicity studies of cyclohexanone oxime administered by drinking water to B6C3F1 mice (CAS No 100-64-1). Toxic Rep Ser. 1996;50:1-E8.

137. Miyake M, Ito Y, Sawada M, Sakai K, Suzuki H, Sakamoto T, et al. Subchronic inhalation exposure to 2-ethyl-1-hexanol impairs the mouse olfactory bulb via injury and subsequent repair of the nasal olfactory epithelium. Arch Toxicol. 2016;90(8):1949-58

138. Hatt H. Geschmack und Geruch. In: Schmidt R, Lang F, Heckmann M, editors. Physiologie des Menschen. Heidelberg: Springer Medizin Verlag; 2010. p. 386-400.

139. Patel RM, Pinto JM. Olfaction: anatomy, physiology, and disease. Clin Anat. 2014;27(1):54-60.

140. Witt M, Hansen A. Strukturelle und funktionelle Grundlagen des Riechens. In: WL HT, editor. Riech-und Schmeckstörungen. Stuttgart, New York: Thieme; 2009. p. 11-26.

141. Muttray A, Klimek L, Letzel S. Toxische Hyposmie und Rhinitis eines Karosseriebauers und Lackierers. Ergo Med. 2003;27:106-11.

142. Welge-Lüssen A, Hummel T. Riechstörungen postinfektiöser, posttraumatischer, medikamentöser, toxischer, postoperativer und anderer Ätiologien. In: Hummel T, Welge-Lüssen A, editors. Riech-und Schmeckstörungen. Stuttgart, New York: Thieme; 2009. p. 77-94.

143. Feron VJ, Arts JH, Kuper CF, Slootweg PJ, Woutersen RA. Health risks associated with inhaled nasal toxicants. Crit Rev Toxicol. 2001;31(3):313-47.

144. Wardlaw SA, Nikula KJ, Kracko DA, Finch GL, Thornton-Manning JR, Dahl AR. Effect of cigarette smoke on CYP1A1, CYP1A2 and CYP2B1/2 of nasal mucosae in F344 rats. Carcinogenesis. 1998;19(4):655-62.

145. Gebel S, Gerstmayer B, Bosio A, Haussmann HJ, Van Miert E, Muller T. Gene expression profiling in respiratory tissues from rats exposed to mainstream cigarette smoke. Carcinogenesis. 2004;25(2):169-78.

146. Baader EW. Chronic cadmium poisoning. Ind Med Surg. 1952;21(9):427-30.

147. Dorman DC, Struve MF, Wong BA, Dye JA, Robertson ID. Correlation of brain magnetic resonance imaging changes with pallidal manganese concentrations in rhesus monkeys following subchronic manganese inhalation. Toxicol Sci. 2006;92(1):219-27.

148. Oberdörster G, Sharp Z, Atudorei V, Elder A, Gelein R, Kreyling W, et al. Translocation of inhaled ultrafine particles to the brain. Inhal Toxicol. 2004; 16(6-7):437-45.

149. Hopkins LE, Patchin ES, Chiu PL, Brandenberger C, Smiley-Jewell S, Pinkerton KE. Nose-to-brain transport of aerosolised quantum dots following acute exposure. Nanotoxicology. 2014;8(8):885-93.

150. Shiga H, Taki J, Yamada M, Washiyama K, Amano R, Matsuura Y, et al. Evaluation of the olfactory nerve transport function by SPECT-MRI fusion image with nasal thallium-201 administration. Mol Imaging Biol. 2011;13(6):1262-6.

151. Shiga H, Taki J, Washiyama K, Yamamoto J, Kinase S, Okuda K, et al. Assessment of olfactory nerve by SPECT-MRI image with nasal thallium-201 administration in patients with olfactory impairments in comparison to healthy volunteers. PLoS One. 2013;8(2):e57671.

152. Colin-Barenque L, Souza-Gallardo LM, Fortoul TI. Toxic effects of inhaled manganese on the olfactory bulb: an ultrastructural approach in mice. J Electron Microsc. 2011;60(1):73-8.

153. Moberly AH, Czarnecki LA, Pottackal J, Rubinstein T, Turkel DJ, Kass MD, et al. Intranasal exposure to manganese disrupts neurotransmitter release from glutamatergic synapses in the central nervous system in vivo. Neurotoxicology. 2012;33(5):996-1004.

154. Guilarte TR, Burton NC, McGlothan JL, Verina T, Zhou Y, Alexander M, et al. Impairment of nigrostriatal dopamine neurotransmission by manganese is mediated by pre-synaptic mechanism(s): implications to manganeseinduced parkinsonism. J Neurochem. 2008;107(5):1236-47.

155. Hoffman HJ, Rawal S, Li CM, Duffy VB. New chemosensory component in the U.S. National Health and nutrition examination survey (NHANES): first- year results for measured olfactory dysfunction. Rev Endocr Metab Disord. 2016;17(2):221-40.

156. Liu G, Zong G, Doty RL, Sun Q. Prevalence and risk factors of taste and smell impairment in a nationwide representative sample of the US population: a cross-sectional study. BMJ Open. 2016;6(11):e013246.

157. Bello G, Dumancas G. Association of 2,4-dichlorophenol urinary concentrations and olfactory dysfunction in a national sample of middleaged and older U.S. adults. Int J Environ Health Res. 2017;27(6):498-508.

158. Noel J, Habib AR, Thamboo A, Patel ZM. Variables associated with olfactory disorders in adults: a U.S. population-based analysis. World J Otorhinolaryngol Head Neck Surg. 2017;3(1):9-16.

159. The German National Cohort. Aims, study design and organization. Eur J Epidemiol. 2014:29(5):371-82

160. Sorokowska A, Sorokowski P, Frackowiak T. Determinants of human olfactory performance: a cross-cultural study. Sci Total Environ. 2015;506507:196-200.

161. Greenberg MI, Curtis JA, Vearrier D. The perception of odor is not a surrogate marker for chemical exposure: a review of factors influencing human odor perception. Clin Toxicol. 2013;51(2):70-6.

162. Palouzier-Paulignan B, Lacroix MC, Aime P, Baly C, Caillol M, Congar P, et al. Olfaction under metabolic influences. Chem Senses. 2012;37(9):769-97.

163. Altman KW, Desai SC, Moline J, de la Hoz RE, Herbert R, Gannon PJ, et al. Odor identification ability and self-reported upper respiratory symptoms in workers at the post-9/11 world trade center site. Int Arch Occup Environ Health. 2011;84(2):131-7.

164. Dżaman K, Wojdas A, Rapiejko P, Jurkiewicz D. Taste and smell perception among sewage treatment and landfill workers. Int J Occup Med Environ Health. 2009;22(3):227-34.

165. Green T, Toghill A, Foster JR. The role of cytochromes P-450 in styrene induced pulmonary toxicity and carcinogenicity. Toxicology. 2001;169(2):107-17.

166. TRGS 522 - technical rule for hazardous substances. Raumdesinfektionen mit Formaldehyd GMBI. 2013;15(1):298-320.

167. Glück U. Macht der Gerüche - krank machend oder belästigend. Schweiz Med Wochenschr. 1996;126:958-66

168. Haehner A, Hummel T, Reichmann H. Olfactory dysfunction as a diagnostic marker for Parkinson's disease. Expert Rev Neurother. 2009;9(12):1773-9.

\section{Ready to submit your research? Choose BMC and benefit from:}

- fast, convenient online submission

- thorough peer review by experienced researchers in your field

- rapid publication on acceptance

- support for research data, including large and complex data types

- gold Open Access which fosters wider collaboration and increased citations

- maximum visibility for your research: over $100 \mathrm{M}$ website views per year

At $\mathrm{BMC}$, research is always in progress.

Learn more biomedcentral.com/submissions 